NBER WORKING PAPER SERIES

\title{
A SURVEY OF EMPIRICAL EVIDENCE ON PATENTS AND INNOVATION
}

\author{
Bhaven N. Sampat \\ Working Paper 25383 \\ http://www.nber.org/papers/w25383 \\ NATIONAL BUREAU OF ECONOMIC RESEARCH \\ 1050 Massachusetts Avenue \\ Cambridge, MA 02138 \\ December 2018
}

This Science Policy Research Report was funded through NSF grant 1732544. I thank participants at the National Academy of Science Innovation Policy Forum "Workshop on Government Decisionmaking to Allocate Scientific Resources" and Gail Cohen, Wes Cohen, Stu Graham, Bronwyn Hall, Diana Hicks, Dick Nelson, Heidi Williams for their feedback and suggestions. The views expressed herein are those of the author and do not necessarily reflect the views of the National Bureau of Economic Research.

NBER working papers are circulated for discussion and comment purposes. They have not been peer-reviewed or been subject to the review by the NBER Board of Directors that accompanies official NBER publications.

(C) 2018 by Bhaven N. Sampat. All rights reserved. Short sections of text, not to exceed two paragraphs, may be quoted without explicit permission provided that full credit, including (C) notice, is given to the source. 
A Survey of Empirical Evidence on Patents and Innovation

Bhaven N. Sampat

NBER Working Paper No. 25383

December 2018

JEL No. O34

\title{
ABSTRACT
}

This report surveys the empirical literature from economics and related fields on patents and innovation. In particular, it reviews and synthesizes the empirical evidence on patents and firstgeneration innovation, the disclosure function of patents, and patents and follow-on innovation. The main results are summarized in fifteen charts.

\author{
Bhaven N. Sampat \\ Department of Health Policy and Management \\ Columbia University \\ 600 West 168th Street, 6th Floor \\ New York, NY 10032 \\ and NBER \\ bns3@columbia.edu
}




\title{
A survey of empirical evidence on patents and innovation
}

\author{
Bhaven N. Sampat (Columbia University and NBER)
}

December 19, 2018

\section{Contents}

1 Introduction $\quad 2$

2 Background, approach, and scope 3

3 Patents and incentives for innovation $\quad 5$

3.1 Evidence from surveys . . . . . . . . . . . . 5

3.2 Evidence from variation in national laws . . . . . . . . . . . . 9

3.3 Quasi-experimental evidence .............. 13

4 Patents, disclosure, and innovation $\quad 13$

5 Patents and cumulative innovation $\quad 15$

6 Caveats and conclusions $\quad 18$

$\begin{array}{llr}7 & \text { References } & 22\end{array}$

$\begin{array}{llr}8 & \text { Figures } & 25\end{array}$

\section{Acknowledgements}

This Science Policy Research Report was funded through NSF grant 1732544. I thank participants at the NAS Innovation Policy Forum's "Workshop on Government Decisionmaking to Allocate Scientific Resources" as well as Gail Cohen, Wes Cohen, Stu Graham, Bronwyn Hall, Diana Hicks, Dick 
Nelson, Heidi Williams for their feedback and suggestions.

The charts from this paper are available here:

https://github.com/bhavensampat/patentreport

\section{Introduction}

In 1951, the British economist Edith Penrose wrote in her Economics of the International Patent System:

If national patent laws did not exist, it would be difficult to make a conclusive case for introducing them; but the fact that they do exist shifts the burden of proof and it is equally difficult to make a really conclusive case for abolishing them.

Later that decade the U.S. Senate Judiciary Committee commissioned a series of reports on the effects of the patent system. Though the authors included Vannevar Bush and other science and technology policy luminaries, the most influential report was from Penrose's colleague Fritz Machlup, a Johns Hopkins Economist. After surveying nearly 200 years of economic theory on the patent system, Machlup's Economic Review of the Patent System similarly concluded:

If we did not have a patent system, it would be irresponsible, on the basis of our present knowledge of its economic consequences, to recommend instituting one. But since we have had a patent system for a long time, it would be irresponsible, on the basis of our present knowledge, to recommend abolishing it.

Though this is less well known, Machlup followed that statement with a more optimistic one for policymakers, noting that if "factual data of various kinds" became available "a team of well trained economic researchers and analysts should be able to obtain enough information to reach competent conclusions" on patent policy.

Sixty years later, an enormous amount of empirical research has been done on patents and patent policy, using a range of research approaches and data sources. This report reviews this work and synthesizes its implications for science and technology policy. The main results are summarized in fifteen charts. 


\section{Background, approach, and scope}

Patents aim to stimulate the development of new products and processes. Under standard patent theory, they do this in two ways. First, by allowing inventors a limited term right to exclude others, patents generate profits associated with market power. These profits are the incentive needed to get inventions developed and to allow firms to appropriate returns from R\&D. The second way in which patents theoretically spur innovation is through encouraging disclosure of information that would otherwise be kept secret. Part of the "grand bargain" of patents is that exclusive rights are exchanged for disclosure of proprietary secrets. In theory, this can help spur innovation if the information disclosed is useful for non-infringing follow-on research, or in replicating the invention after patents expire.

Under the classic theory of patent protection, these benefits for innovation must be weighed against the costs generated by monopoly pricing and limited competition. In economic parlance, patents aim to balance "dynamic efficiency" (innovation) and "static efficiency" (marginal cost pricing). Unlike many other science and technology policies, patents are a "pull" policy, and the way in which society pays for inventions and their disclosure is not through up front funding but paying instead through higher than competitive prices (and restricted output) for a limited period of time, until the patents expire.

While this framework would have been familiar to Penrose, Machlup and their contemporaries time economists and others have recognized that in some contexts and fields innovation is not a one-shot deal but rather cumulative. Today's research outputs can be inputs into tomorrow's followon innovation. The effects of patents on innovation are more complicated in this case, since stronger patents could create incentives for first-generation innovation, but make second generation innovation more costly or difficult (Scotchmer 1991; Merges and Nelson 1990). This is not just a theoretical concern, but has been one of the central concerns in patent policy in recent years.

This report surveys the empirical evidence on the effects of patents on first generation and follow-on innovation. The review is based on searches in the Web of Knowledge and Google Scholar, as well as a review of references in previous survey articles on the costs and benefits of patents. ${ }^{1} \mathrm{~A}$

\footnotetext{
${ }^{1}$ These include Gallini (2002), Hall and Harhoff (2012), Mazzoleni and Nelson (1998), Williams (2017), Boldrin and Levine (2013), Budish et al (2016), Williams (2016), Moser
} 
short report must make difficult choices about what to include and ignore. With one exception (a working paper with over 3000 citations), this review focuses on published articles rather than working papers. This means very recent research is ignored, which is potentially an important omission given the recent surge of research on the effects of patents, including quasiexperimental work patents and follow-on innovation, and on the disclosure function of patents.

There is probably more recent writing on patent policy than any other science and technology policy instrument, and space restrictions also limit the ground that can be covered. One important topic that this report discusses only tangentially is the effects of patents on markets for technology and on technology transfer (Arora and Gambardella, 1990; Lerner and Merges, 1998). This is important not only for assessing the importance of patents for sector research, but also for evaluating the Bayh-Dole Act and similar legislation which allowed for patenting of publicly funded research (Mowery et al 2004).

Additionally, the review focuses on evidence on the upside of patents, not the net benefits. While it does examine some of the costs of patent protection (primarily those associated with effects on follow-on innovation) it does not deeply engage research on the higher prices associated with patented products-most of which is conducted by health economists studying pharmaceuticals-and associated effects on access to medicines. In addition to these classic costs, there are also others, including litigation costs, licensing costs, and costs associated with increased uncertainty. These are thought to be particularly high in fields like business methods, software, and others where benefits for patent protection may also be less important (Lerner 2002; Bessen and Meurer 2008) and quality of granted patents also more suspect (Sampat 2010; Merges 1999). These are important issues that should also, naturally, be incorporated into thinking about patent policy. Nonetheless, the accumulated body of evidence on the effects of patents on innovation is itself useful in thinking about many issues in patent policy design.

Below, I discuss representative studies on the effects of patents on innovation incentives, the effects of patent disclosure on the diffusion of knowledge and innovation, and the effects of patents on follow-on research. In most cases, the results from the studies are summarized graphically.

(2013), and Jaffe (2000). 


\section{Patents and incentives for innovation}

\subsection{Evidence from surveys}

The first attempts to quantitatively study the effects of patents on innovation were based on surveys of R\&D performing firms. The findings of these studies (which have since become an empirical regularity) were surprising at the time and posed challenges for the classic theory of patent protection. In most fields, firms relied on other mechanisms to appropriate returns from R\&D. Patents simply were not that important in creating R\&D incentives.

A first survey by Scherer et al (1959) surveyed 69 companies holding 45,500 patents and found that first-mover advantages and lead time were more important than patents in shaping firms' decisions to invest in innovation. Shortly afterwards, a survey by Cambridge University economists of British companies asked how much R\&D expenditures would drop if patents were replaced with compulsory licenses with modest royalties. The responses indicated a modest overall reduction of 8 percent (Taylor and Silberston 1973). However (anticipating results of later work) the report indicated that the impact in pharmaceuticals would be much larger without patents: a 64 percent reduction in R\&D.

Mansfield (1986) surveyed a random sample of 100 large R\&D intensive U.S. manufacturing firms. Among other questions, the study sought to answer "[t]o what extent would the rate and development and commercialization of inventions decline in the absence of patent protection" (173). Unlike previous studies on these issues, this study focused on a range of industries and a random sample of firms. Figure 1 shows the main results. Mansfield found sharp cross-industry differences in the importance of patents, with respondents indicating that 60 percent of drug inventions and 38 percent of chemical inventions would not have been developed in pharmaceuticals and chemicals respectively. In most other industries, respondents claimed that the vast majority of inventions would have been developed without patent protection.

A similar study was conducted by Richard Levin and colleagues (1987). The so-called "Yale study" also focused on high-level R\&D executives, but used a broader sample (focusing on over one hundred manufacturing industries), and paid more attention to survey design issues. The sampling frame was FTC defined lines of business, and the investigators received 
responses from 650 individuals from 130 lines of business. (The study focused on public firms, so small firms were underrepresented.) Unlike Mansfield, the Yale study used a semantic Likert scale to rate patent importance. Also different from Mansfield (but similar to Scherer survey), the Yale study tried to examine the importance of patents relative to other means through which firms appropriated returns to R\&D on new products and processes. This helped in resolving a key question from the Mansfield survey and earlier work: if patents are not effective in many industries, how do firms appropriate returns from $R \& D$ ?

One of the questions asked respondents to rank, on a scale from 1 (not at all effective) to 7 (very effective), how important particular modes of appropriation were to protect the competitive advantage from new products and processes. Figure 2 shows results for product innovations. Strikingly, overall across industries learning curves, complementary assets (sales, service) ranked higher than patents as a way to appropriate returns from innovation. Figure 3 shows that differences across industries in this measure closely track those from the Mansfield survey. There are large interindustry differences, and patents are more effective in pharmaceuticals and chemicals than other fields. The authors of the Yale study also speculated on why pharmaceutical and chemical industries ranked patents more highly. They conjectured that patent boundaries are relative clear in these "discrete" product industries than "complex" industries where innovations are part of large and complex systems.

The authors also point to the limitations of their analysis, including that firm policies or strategies may influence their perceptions and the subjective nature of Likert rankings. Firms were asked to describe typical firm in their industry, but the fact that the sample included few small firms means that responses may understate the value of patents, to the extent they are more important to small firms. Later work, in particular the Berkeley study, tried to address this.

The third in this line of U.S. surveys was the Carnegie Mellon survey (Cohen, Nelson, and Walsh 2000), which was broadly interested in the nature and determinants of industrial R\&D. As part of this survey, the CMU investigators revisited the questions in the Yale survey for several reasons, including to improve on survey design (question wording, definition of response scales, and sampling strategies) and to reflect changes in the legal environment that strengthened patent protection over the 1980s and 1990s (including the creation of the Court of Appeals for the Federal Circuit in 
1982, changes in patent- eligible subject matter, and other factors). The CMU study also sought to understand a puzzle from the Yale study: why firms take out patents even in industries where patents are reported to be relatively ineffective modes of appropriating returns from $R \& D$.

The CMU survey was administered in 1994 to a random sample of R\&D performing labs in the manufacturing sector, a much broader firm size distribution than the Yale survey. It sampled 3240 labs and received 1478 responses. In reporting the results the investigators focus on firms with 5 million dollars in US sales or business units of 20 people, yielding 1165 responses.

Like the Yale study, the CMU survey asked respondents about the percentage of innovation for which different appropriability mechanisms were effective in protecting the firms' competitive advantage from innovation during the previous two years. Though the response scales were different, the results for patents are similar to those from the Yale study and are reported in Figure 4. Overall, patents are the least important of the major apppropriability mechanisms. But as Figure 5 shows there was again considerable heterogeneity across industries, with patents being particularly important in drugs and chemical based industries (like in the Yale study) but also for medical equipment and computers. (In no industry, however, were patents the most important mechanism for product innovations.) In a careful analysis of changes over time, the authors found that the relative importance of patents had grown modestly since the Yale survey. But the most significant change over time was the growth in importance of secrecy as an appropriability mechanism.

One question the CMU investigators sought to explore is why, given a modest change in the importance of patents, patenting grew sharply between the 1980s and 1990s. To do so, they also asked respondents about their reasons for applying for their most recent patents. Figure 6 shows the overall results. The classic rationale (preventing copying) dominated. But frequently firms also indicated other reasons for patenting, including to block rivals from patenting (for 82 percent for patented innovations) and prevent lawsuits (for over 50 percent of patented innovations). The authors also showed that these other strategic reasons for patenting were more commonly employed in complex product industries (which tend to have many patents per product) than in discrete product industries such as drugs and chemicals (which tend to have one main patent per product). Indeed, in complex project industries, 55 percent of respondents claimed 
that use in negotiations is an important reason for patenting, compared to just 40 percent in discrete product industries. This idea, that in complex product industries in particular firms may accumulate patents for strategic purposes (beyond the classic use of patenting to prevent copying) has found support in other papers as well (Hall and Ziedonis 2001). ${ }^{2}$ Among other implications, this suggests that changes in patent policy, even if they increase incentives to patent, may not necessarily increase the rate of innovation. Indeed, in these contexts, stronger patents may also harm innovation in contexts where innovation is cumulative, as discussed more below.

The Mansfield, Yale and CMU surveys provided much nuance to how patent systems function in practice that was simply not available at the time Penrose and Machlup wrote. Similar innovation surveys have been conducted globally since then. For example, the European Community Innovation Survey (CIS) asked European Union firms about the importance of patents vs. other appropriability mechanisms, with similar results to those from Yale and CMU (Arundel et al 1995). The Yale investigators, together with Akira Goto and Akira Nagata conducted a survey of R\&D managers in the U.S. and Japan (Cohen et al 2002). This survey found similar levels of absolute effectiveness of patents in the U.S. and Japan as an appropriability mechanism. More intriguingly, it found that Japanese patents tend to be more valuable as a source of information than U.S. patents, suggesting the disclosure function of patents may have more force in Japan, a finding discussed in more detail below.

A more recent survey in the U.S. was the Berkeley Patent Survey (Graham et al 2009). Previous surveys of the importance of patents had underrepresented small firms. The Berkeley survey focused on 1,332 early stage companies founded between 1998 and 2008. When matching the sample firms to respondents, the authors found that startups held an average of 4.7 patents and patent applications. But there are strong cross-industry differences, with more patent holding in life sciences than other fields, consistent with what we would expect from the Mansfield, Yale, and CMU surveys. The investigators asked executives at these companies how strong or weak an incentive patent provided for innovation-related activities. Overall, the respondents replied that patents offer between a "slight" and "moderate" incentive to innovate. But here again there were strong cross-industry differ-

\footnotetext{
${ }^{2}$ Cohen et al 2002 refer to the use of patents to block other firms in order to facilitate cross-licensing and improve bargaining power in licensing negotiations as "player" strategies.
} 
ences, with biotechnology firms reporting "moderate" incentives and software firms "slight" incentives. The investigators also asked respondents to rank different appropriability strategies. Figure 7 shows the results, by broad technology sector. Patents are the most important mechanism for biotechnology startups. This is different from the CMU survey, where patents rank second to secrecy. In medical devices only first mover advantages are more important as a way to secure competitive advantage. In IT hardware too patents were eclipsed only by first mover advantages. This is in stark contrast to CMU, where hardware firms ranked patents lowest. These results suggest that patents may have different importance to startup firms than others. However, this was not uniform across industries: for software firms patents are the least effective source of competitive advantage. The survey authors also tried to unpack "competitive advantage" by asking respondents for their reasons for patenting. Overall, and across industries, the most important reason for patenting appears to be to prevent others from copying their inventions.

\subsection{Evidence from variation in national laws}

Another way in which economists and others have tried to assess the impact of patents on innovation is to exploit variation across countries in patent laws, and in particular variation in patent laws.

Sakakibara and Branstetter (2001) examined 1988 changes to patent claiming procedures which they argue increased patent scope - the product space covered by patents. One question in these kinds of studies is always how to measure the outcome variable. Sakakibara and Branstetter use two approaches that would later be common in the literature. First, they looked at firm-level R\&D expenditures for Japanese firms. Second, they look at patenting in a "neutral" country not affected by the reforms, i.e. the U.S. The reason for doing so is that counting domestic patents alone might conflate the effects of patent policy changes on the propensity to patent with those on actual innovation, a concern which is ameliorated by looking at patents in another important market.

The study began by examining changes over time in the R\&D intensity of Japanese firms, finding about a 9 percent increase after the strengthening of protection. However, robustness checks cast doubt on the interpretation of this change over time as the causal impact of patent strengthening. In particular, the effect was smaller among patent-intensive firms, was ex- 
tremely sensitive to exactly when the reform is assumed to have occurred, and had a negative or insignificant impact in the most patent intensive industries. Similar results were seen when examining Japanese patenting in the U.S. before and after the reforms. The authors concluded that in this case strengthening of patents had no impact on innovation.

Lerner (2009) took a similar approach, but for a much broader set of countries and a much broader set of changes. Specifically, he examined 60 countries between 1850 and 1999, and compiled various measures of the strength of patent protection. He then examined how patent policy strengthening and weakening related to innovation, as measured by patent filing in a neutral country, this time Great Britain. He also examines the effects of these changes on patent applications by domestic and foreign entities in the country affected.

Figure 8 shows the basic results from this study for patent system strengthening. The amount of innovation, as measured by patenting in Great Britain, was unaffected by these changes. And domestic patent application volume actually decreased, while foreign patent activity in the country increased in response to patent strengthening. Unfortunately, this study was unable to differentiate patents by sector, which seems important in light of the previous survey research discussed above.

Other important work exploiting cross-national variation in patent laws comes from a series of papers by Petra Moser. An important feature of Moser's work is that it typically used non-patent measures of innovation. This is important since it can be difficult, as discussed above, to untangle effects of patent law changes on innovation from those that simply increase patenting propensity.

Moser (2005) related features of patent systems, and changes in patent laws, to exhibitions at two nineteenth-century world fairs: the Crystal Palace Exhibition in London in 1851 and the Centennial Exhibition in Philadelphia in 1876. This allowed her to look at innovation in countries with and without patents. She grouped the exhibitions to 7-10 industries and used Lerner's data on strength of patent laws. She found evidence that patent laws affect the direction of innovation in countries without patent laws. In these countries, inventors shifted to industries where patents are not important (presumably using other appropriability mechanisms). She also found that countries without patent laws contributed a substantial amount of innovation (Moser, 2013), but primarily in industries where other mechanisms (in particular, secrecy) was effective. This suggests that an important 
effect of patent laws may be on the direction of innovation and not just its rate. Moser also found that a small share of exhibitions are patented at all, emphasizing the importance of looking at non-patent measures of innovation in the empirical analyses. In another historical paper using a nonpatent measure of innovation, Moser and Rhode (2012) examined how the Plant Patent Act of 1930 affected innovation in roses, as measured through rose registration data. The authors found that there is little or no effect of the patent act on innovation in roses.

In nearly all of the surveys discussed in the previous section, the pharmaceutical sector was the one where patents seemed most important for R\&D choices. However, all of these surveys focused on individual rich countries and their patent laws. Before the World Trade Organization's 1995 TRIPS (Trade Related Intellectual Property Rights) Agreement, most developing countries did not allow drug product patent protection. Even if pharmaceutical patents in rich countries were important for domestic innovation, it is not obvious that patent protection in less developed countries would be, since (among other reasons) potential innovators in these countries may already be incentivized by protection in patent-protected rich country markets. Qian (2007) examined this empirically, looking at domestic innovation in 26 countries that established pharmaceutical patent laws during the 1978-2002 period. As in Sakakibara and Branstetter (2001) and Lerner (2009), this study used patents in a neutral country, the U.S., as its main measure of innovation. To account for the well-known skew distribution of patent value, the study weighted patents by "forward" citation counts. (It also looked at other outcome measures in robustness tests, including R\&D expenditures for a subset of countries where these data are available, as well as pharmaceutical exports.) Finally, the study aimed to account for a major issue in these types of studies - that the timing of patent law enactment (and details of implementation) are not random. Qian did so through using matching techniques to create control samples among the 92 countries that did not have patent law changes over this period. Overall, her analyses suggested no effect of changes in patent laws on the measures of domestic innovation. For example Figure 9 plot log citation weighted patent counts in treated countries in the years before and after implementation of pharmaceutical patents, showing no obvious trend. Similar results were seen in the regression analyses, which compared trends to the control countries to account for a number of potential omitted variables. However, Qian does find some evidence that introduction of drug patent laws 
enhanced innovation for countries that are relatively more developed.

Kyle and McGahan (2012) more explicitly examined the effects of the TRIPS agreement. While the Qian paper focused on whether drug patent protection would increase innovation by domestic firms in the countries that introduced this protection, the Kyle and McGahan paper examines whether drug patent protection in one country (and the globalization of drug patent protection through TRIPS) spurred research by firms in other countries. The theoretical literature on TRIPS (e.g. Subramanian 2004) suggests it is unlikely that patents in developing countries would affect research incentives on global diseases (such as cancer or cardiovascular disease) since developing countries are a small part of the market for these drugs. However, it leaves open the idea that this protection would spur research on "tropical" diseases that do not have rich country markets. This paper can help us understand how and when patents incentive innovation more generally. As the authors say: "If patent protection is effective in inducing innovation, then we should observe more $R \& D$ on diseases relevant to local populations as patent protection was extended to developing and least-developed countries. Instead, if patents are ineffective at inducing R\&D on so-called neglected diseases, then no response in R\&D effort would occur with the extension of patents to poor countries" (1157).

To examine this question, they looked at data on pharmaceutical patent protection and research by disease over the 1990-2006 period. This paper, too, examined a non-patent measure of $R \& D$, the number of drugs in Phase I clinical trials for a disease. Figure 10 shows the estimated effects of patents in different types of countries on different types of diseases.

The authors found that in high income countries, R\&D was more responsive to market size for global and neglected diseases when there is patent protection. However, this was not true in poorer countries. They conclude that drug patents in developed countries do affect innovation incentives in developed countries, but drug patents in developing countries do not. Like previous work, they acknowledge several limitations to their analysis, including that the timing TRIPS implementation may be non-random, and that countries may be implementing drug patent laws in very different ways. 


\subsection{Quasi-experimental evidence}

Beyond using national patent laws as a source of variation, there are very few papers using quasi-experimental sources of variation to assess the effects of patents on innovation. One exception is recent work by Budish et al (2015) which examined variation in research (measured by clinical trials) across different cancers. The paper argued that the effective length of patent protection may be lower for cancers that have longer survival times, because these will also have longer clinical trials. Using data on all clinical trials on all cancers over the last three decades, the authors found strong evidence to support the hypothesis that longer commercialization lags lead to less R\&D. This is consistent with the idea that cancers with shorter effective patent terms have less research. (Figure 11) However, the authors were careful to note that the result that longer commercialization lags are associated with less R\&D could reflect factors beyond patents as well, including short-termism of firms, and that it is difficult to untangle these two effects.

\section{Patents, disclosure, and innovation}

The other classic way in which patents are said to influence innovation is via disclosure of information. Much of the legal scholarship on patent disclosure is critical of theory, suggesting that disclosure is in fact inadequate. The main reasons for this skepticism include arguments that applications do not in fact enable, are deliberately written to obfuscate, that much relevant knowledge to enable is "tacit" and costly (perhaps even impossible) to codify in patent documents, and that firms may themselves face disincentives (because of the doctrine of willful infringement) to search for previous patents (Ouellette 2011; Fromer 2008; Devlin 2009). There is also theoretical literature suggesting that only inventions that would already have been disclosed absent patents would be patented; else firms would rely on secrecy instead.

There is less empirical work on the impact of patent disclosure on innovation than on the impact of patents on innovation incentives, and most of the relevant work is survey research. The Yale study asked respondents about reasons they do not patent and found that, for both products and processes, greater than 60 percent of firms responded that ability to invent around patents was moderate-very important. The CMU survey also asked respondents about the reasons they do not patent. Figure 12 shows the 
most important reasons reported by firms for not patenting (for unpatented inventions): inventing around and disclosure (together) were cited nearly half of the time.

This provides at least indirect evidence that patents disclose useful information. Similar analyses were conducted in the Cohen et al (2002) survey of U.S. and Japanese firms. This is particularly interesting since, at least according to some observers (Ordover 1991), several features of the Japanese patent system made it historically more "pro-disclosure" than the U.S. patent system. ${ }^{3}$ Consistent with this idea, in this survey nearly half of Japanese firms (46 percent) cited concerns about disclosure as the most important reason to not patent, which was nearly twice that of U.S. firms. Another question more directly related to the impact of disclosure asked firms about the importance of different ways they learn from other firms (focusing on information sources for a recently completed R\&D project). Figure 13 shows that in Japan patents were the most important source. In the U.S. about half (49 percent) of R\&D projects ranked patents as moderately or very important information sources.

Similarly, the PatVal-EU survey of inventors on about 30,000 patents granted by the European Patent Office (EPO) during the 1990s asked about the importance of patents relative to other sources of knowledge for their patented inventors. That patent literature ranked second only to customers and users as a source of innovation. The importance of patents as a source of information was similar to that of scientific literature. A more recent study in the U.S. by Ouellette (2012) surveyed nanotechnology researchers. Among the 211 respondents (mainly academic nanotechnology researchers) 64 percent had read a patent. Among them, about 30 percent (64) had read a patent for technical information and found useful information there. However, only 38 percent felt that patents were reproducible based on reading them.

\footnotetext{
${ }^{3}$ Specifically Ordover argued that the Japanese first-to-file system (granting patent priority to the first inventor to file) was more conducive to disclosure than the first-to-invent system that the U.S. had at the time he wrote, since first-to-file, coupled with Japanese pregrant publication laws, led to earlier filing and making public of the information in the patent text. Note that in 2000 the U.S. began requiring pre-grant publication of most applications 18 months from filing, and in 2012 the U.S. transitioned to a first to file system. It is also possible that the Japanese pre-grant opposition system that was in place until 1996 (allowing competitors to challenge patent applications that were pending) facilitated disclosure by creating incentives for competitors to monitor one anothers' applications (Cohen et al 2003).
} 
Collectively these surveys suggest that patents do contain useful information, contrary to some commentary (Fromer 2008; Devlin 2008). However, they stop short of indicating the effect of patent disclosure on innovation. Were the information disclosed in patents removed, would innovation suffer markedly? Were patents not available, would there be less innovation tomorrow because of reduced disclosure of technical information today? Unlike the work on patent as incentives for innovation, there is very limited quasi-experimental work on this question. One exception is another paper by Petra Moser (2011) using exhibition data, which showed that as chemical inventors shifted from secrecy to patents in the mid-nineteenth century (due to the publication of the periodic table in 1869, which made chemicals easier to reverse engineer), the geographic localization of inventions weakened. ${ }^{4}$

\section{Patents and cumulative innovation}

In the literature on disclosure, patents can enable follow-on invention by providing information that is an input into later inventions. The disclosure literature focuses on follow-on innovation that is non-infringing. A different question is in the context of cumulative research, when tomorrow's invention relies on access to a previous patented product or process. As Scotchmer (1990) has argued, patent policy in the context of cumulative innovation is harder than when innovation is a one-shot deal, since patents must be strong enough to incentivize first generation research but not too strong as to make later innovation too costly. The net effect of patent strength (or length or breadth) on innovation is theoretically ambiguous for cumulative innovation. ${ }^{5}$ Indeed, part of the concern about the growth of patenting in IT, software, and other complex product industries discussed above (Cohen et al 2000; Hall and Ziedonis 2001) is precisely because innovations in these industries tend to be cumulative and interdependent, compared to discrete product industries such as pharmaceuticals.

Much of the work on patents and follow-on research comes in the con-

\footnotetext{
${ }^{4}$ Hegde and Luo (2017) and Graham and Hegde (2015) exploit the 1999 American Inventors Protection Act (AIPA) which forced publication of U.S. Patent Applications 18 months after filing to answer a different question: how patent disclosure may create private benefits to patentees.

${ }^{5}$ Complicating things further, Kitch (1977) suggests that patents may facilitate follow on innovation by allowing the innovator to efficiently manage downstream R\&D.
} 
text of biomedical research, and in particular the growth of patenting of upstream academic research (including genomic information) following the 1980 Bayh-Dole Act (Mowery et al 2004; Eisenberg 2003; Eisenberg and Heller 1998). A survey by Walsh, Cho, and Cohen $(2005,2007)$ of academic biomedical researchers found that despite concern among policymakers, few of those survey reported that their research was restricted by previous patents on research tools. (Most were not even aware of the previous patents.) However, the authors found that commercially- oriented researchers were more likely than non-commercially oriented researchers to report that availability on unreasonable terms (whether due to patents or other factors) was a reason for not pursuing a follow-on research project.

Murray and Stern (2007) also examine the effects of patents on followon medical research. Specifically, they examine patent-paper "pairs" based on 340 articles published in Nature Biotechnology between 1997 and 1999. Patent-paper pairs are cases where the information in the article was covered by a patent. About half (169) were granted patents by 2003. The analysis estimates negative binomial regressions with the number of citations to the article as the dependent variable and years before and after patent grant as independent variables. The model includes article fixed effects, controlling for the average quality of the article. Overall there is about a 10 percentage point decline in citations to an article after a patent issues. Figure 14 shows the evolution of the effect over time. The decline appears to begin immediately after patent issue and continues in subsequent years. There is about a 25 percent difference between the pre-grant average and the citation level four years after patent issue

Murray and Stern find this effect is most pronounced for tangible "composition of matter" discoveries, and less so for research tools. This finding is surprising: as the authors emphasize, previous concerns about patents and follow on research were focused mainly on research tools. However, it is consistent with the Walsh et al (2007) finding that while patents, in general, don't negatively affect follow-on research, control of tangible materials does. One reason why is that tangible discoveries require affirmative consent (and sometimes negotiation, formal contracts, and payment) for access.

The Murray and Stern (2007) sample of Nature Biotechnology articles spanned the 1997-1999 period. A subsequent paper (Fehder, Murray, and Stern 2014) included articles from this journal published from 1997-2005, and also considered articles from another journal (Nature Materials) pub- 
lished between 2002-2005 as well as patents associated with each of these articles. Using the same empirical framework as Murray and Stern (2007), the authors find while the impact of the patent grant is negative in early years of the journal, subsequently it is positive, and the net impact of patents on follow-on innovation is positive. This positive effect is concentrated among private sector researchers: a 21 percent increase in citations following patent issue from these researchers, compared to a 6 percent increase for public sector researchers. Rather than hindering follow-on research, the authors suggest that once a journal becomes established it may actually help facilitate "markets for technology" for patented research. The effect of patents on follow-on innovation thus appears sensitive not only to type of discovery (tangible versus intangible) but also to specifics of the institutional context.

The idea that specific institutional factors mediate the impact of property rights on follow-on research also finds indirect support in recent work on genomic patenting and follow-on research. Sampat and Williams (2019) examine the impact of genomic patents on follow-on research. This paper uses two quasi-experimental approaches (differences in outcomes between applications that are and are not granted, and differences in grant outcomes based on leniency of the patent examiner to which the application was assigned) to estimate the causal impact of gene patents on three different measures of follow-on innovation (scientific publications, diagnostic tests, clinical trials). It finds that gene patents do not have strong negative (or positive) effects on follow-on innovation. By contrast, in previous research Williams (2013) had found that a private firm's (Celera's) ownership of portions of the genome (through a proprietary database, not patents) led to large declines in follow-on research. One potential reason for the difference is that patents on genes typically disclose and make open access sequences. By contrast database access, (like control of "tangible" research inputs which both Cho et al and Murray/Stern find can negatively impact research), requires the owner to formally grant access.

Sampat and Williams also speculate that pro-disclosure policies for gene patents and applications (specifically the USPTO policy to require genomic applications to explicitly report the claimed DNA sequences ) may have helped enable potential follow-on innovation, i.e. given force to the disclosure requirement beyond what is typical for patents in other fields. Earlier (in the discussion of the U.S. vs. Japan) I noted that some scholars argue that the extent to which patents effectively disclose information may vary 
according to features of the patent system. It could also be that the specific implementation of the disclosure requirement (as in genomics) may matter; this is an important topic for future research.

One of the few papers on patents and follow-on innovation that covers a large number of technological fields is Galasso and Schankerman (2014). The authors looked at patents that were reviewed by the Court of Appeals for the Federal Circuit. The study took advantage of the fact that judges assigned to patent cases are randomly assigned and have different levels of invalidation, creating a natural experiment to assess the causal impact of patent invalidation. The results, summarized in Figure 15 below, indicate that patent invalidation resulted in about a 50 percent increase in followon research, as proxied by the number of later patents citing the invalidated patent. However, there were strong differences across fields: the effects of patents on follow-on research were concentrated in computers and communications, electronics, and medical instruments/biotechnology, and there is no statistically significant effect for drugs, chemical, or mechanical technologies.

What, then, can we conclude about the impact of patents on follow-on innovation? Taken together, most the the studies specifically focused on the life sciences can reject a negative effect. The Galasso and Schankerman (2014) study, the only one that looked at a range of fields, finds a negative effect of patent grants on citations, but with strong differences across technology classes. Going forward, a better understanding of the sources of heterogeneity suggested by the existing literature (differences across fields, tangible vs. intangible property, public vs. private sector researchers) is needed, and is a fruitful topic for research.

\section{Caveats and conclusions}

The evidence presented above is from various types of studies: surveys, changes in national laws, and various historical and contemporary quasiexperiments. Each of these approaches has advantages and disadvantages, naturally.

For example, while the surveys directly ask firm managers about the importance of role patents, the responses are based on stated preferences and not actual choices. If, for example, the pharmaceutical industry "culture" were pro-patent and the software industry anti-patent, that could help 
explain how respondents answered. (The fact that cross-industry results are so consistent over time and across countries helps alleviate this concern.) A second issue with at least some of the surveys, those using Likert responses, is that these can be difficult to translate these to specific economic magnitudes. A third is semantic comparability: concepts like "important for innovation" or even "innovation" may be interpreted differently across fields. Yet another issue is coverage: as I mentioned above many of the surveys focused on large firms, and the impact of patents on innovation may vary by firm size. ${ }^{6}$

The benefit of natural and quasi-experiments over surveys is that they are based on actual choices in response to economic changes, not stated preferences. The most common approach looked at changes in national policy laws. Several of the issues with these approaches have already been raised above, including that the timing of the changes may not be random. If for example countries that expected to become more innovative also strengthened their patent laws, this would overstate the causal impact of patent protection. The ways in which patent laws are implemented may be different across countries: measurement error could lead to underestimating the impact of patents on innovation. It is important to be careful about generalizing from these experiments too: for example, evidence on changes in drug patent laws in developing countries may be relevant for the TRIPS debate, or about patent provisions in future trade agreements, but less so for thinking about changes in drug patent policy in a country like the U.S. (Budish, Roin, Williams 2017). Finally, only a few of the natural experiments (the ones that focus mostly on pharmaceuticals or economic history) use non-patent measures of research or innovation to assess impact, because such outcome measures are not easily found.

All of these caveats notwithstanding, several conclusions emerge from the review:

- The effects of patents on innovation incentives are stronger in some sectors (pharmaceuticals, chemicals) than others. The effects of patent policy on innovation are likely to be sector specific, as are the costs and benefits of patent strengthen or weakening patent protection. An optimal patent policy would be sector specific. While this may be difficult to achieve formally given current international law, potential for

\footnotetext{
${ }^{6}$ In general, there may be within-industry heterogeneity may be masked by overall averages.
} 
gaming, and blurry boundaries across fields, "tailoring mechanisms" such as patent office guidelines for different fields could help move the system in that direction (National Research Council, 2004). ${ }^{7}$

- Patents are used differently across fields. In some fields, they are important ways in which firms appropriate returns from R\&D. In others, they are less important for these purposes but are used for other strategic purposes.

- A considerable amount of innovation occurs outside the patent system. Strengthening of patent protection leads to changes in patenting and patent propensity, but this is not necessarily correlated with more innovation.

- In a global environment, strengthening national patent laws outside the U.S. does not seem to matter much for domestic R\&D or innovation. Even in pharmaceuticals, the sector where patents are most important, domestic patent protection has limited impact on measured R\&D or innovation.

- Stronger patent protection does not appear to generate R\&D for "tropical diseases." For high social value investments without significant markets, patents are unlikely to have a strong effect. Other mechanisms, including prizes or public funding, may be needed.

- Despite much commentary to the contrary in the theoretical literature, firms do seem to read patents for information and learn from them. The design of patent systems and specific rules surrounding disclosure may affect the extent of disclosure of useful information in patent documents. However, the quantitative effects of the disclosure function of patents on rates of innovation are not well known.

- Evidence for the claim that patents hinder follow-on innovation is mixed. Most of the work specifically focused on the life scienceswhere policy concerns have been greatest- can reject any strong negative impact of patents on follow on innovation. In general, the research points to heterogeneous effects of patents on cumulative innovation: the effects appear to depend on the type of knowledge

\footnotetext{
${ }^{7}$ Empirical assessment of the effects (intended and otherwise) of patent office guidelines used in the past would also be useful.
} 
patented (tangible vs. intangible), the locus of potential follow-on researchers (public vs. private), technology field, and various other institutional factors.

Many of the issues above (especially the last three) are topics of ongoing research. While it would be foolish to make definitive statements on most of these issues, we can move past the extreme uncertainty expressed by Penrose, Machlup and others and provide some guidance for policymakers on the issues above. This represents an initial payoff from the large body of empirical research on patents that has been conducted over the past decades.

But more is to be done. With the recent growth in availability of machinereadable patent data, as well as interest in exploiting quasi-experimental variation in patent laws or strengths, we should expect to see much more work going forward on these issues. Five issues seem particularly important. First, while much of this review has followed the literature and focused on the benefits of patent protection, we need better quantitative assessments of the real static costs of patent protection (not just in pharmaceuticals) and more work on the effects of patents on follow-on research. Understanding the costs of patent protection better is particularly important since, as Machlup himself noted, the important question is not whether patents are good for innovation but whether they get us the innovation we want at lower cost than other alternative S\&T policy instruments (e.g. prizes or public funding). Second, more evidence is needed on the disclosure function of patents. While there is considerable survey research, this seems like an area where there are returns from more quasi-experimental approaches, for example, by exploiting changes in disclosure rules or policies. Third, more work is needed on assembling and validating non-patent indicators of innovation, since it is difficult to assess the impact of patent policies with patent data alone. "Real" measures of innovation beyond patents are needed, both to use as independent outcome measures but also to validate the patent (and patent citation) based measures that are now widely available and commonly used. Fourth, in assessing the impact of changes in national patent laws, better understanding is needed on the nuances and timing of implementation. Finally, while many of the studies above are relevant for thinking about the effects of patents on average, the relevant policy discussions are often marginal (e.g. increasing the patent term by several months, extending patents to a particular field or country, 
limiting certain types of patents). More research on these types of changes could also be useful. In some contexts, policymakers might also be able to help facilitate research and evidence-based policy as well by rolling out the policies in a way that is conducive to rigorous evaluation.

\section{References}

Arora, Ashish, and Robert P. Merges. "Specialized supply firms, property rights and firm boundaries." Industrial and Corporate Change 13.3 (2004): 451-475.

Arundel, Anthony. Innovation Strategies of Europe's Largest Industrial Firms: Results of the Survey for Information Sources, Public Research, Protection of Innovations and Government Programmes; Final Report. MERIT, 1995.

Boldrin, Michele, and David K. Levine. "The case against patents." The journal of economic perspectives 27.1 (2013): 3-22.

Budish, Eric, Benjamin N. Roin, and Heidi Williams. "The Design and Use of Patents Patents and Research Investments: Assessing the Empirical Evidence." The American economic review 106.5 (2016): 183-187.

Cohen, Wesley M. "Fifty years of empirical studies of innovative activity and performance." Handbook of the Economics of Innovation 1 (2010): 129213.

Cohen, Wesley M., et al. "R\&D spillovers, patents and the incentives to innovate in Japan and the United States." Research policy 31.8 (2002): 1349-1367.

Cohen, Wesley M., Richard R. Nelson, and John P. Walsh. Protecting their intellectual assets: Appropriability conditions and why US manufacturing firms patent (or not). No. w7552. National Bureau of Economic Research, 2000.

Cohen, W.M., Goto, A., Nagata, A., Nelson, R.R. and Walsh, J.P., 2003. R\&D information flows and patenting in Japan and the United States. In Economics, Law and Intellectual Property (pp. 123-154). Springer, Boston, MA.

Devlin, Alan. "The misunderstood function of disclosure in patent law." Harv. JL \& Tech. 23 (2009): 401.

Fromer, Jeanne C. "Patent disclosure." Iowa L. Rev. 94 (2008): 539.

Galasso, Alberto, and Mark Schankerman. "Patents and cumulative in- 
novation: Causal evidence from the courts." The Quarterly Journal of Economics 130.1 (2014): 317-369.

Gallini, Nancy T. "The economics of patents: Lessons from recent US patent reform." The Journal of Economic Perspectives 16.2 (2002): 131-154.

Graham, Stuart JH, et al. "High technology entrepreneurs and the patent system: Results of the 2008 Berkeley patent survey." Berkeley Technology Law Journal (2009): 1255-1327.

Graham, Stuart, and Deepak Hegde. "Disclosing patents' secrets." Science 347.6219 (2015): 236-237.

Hall, Bronwyn H., and Dietmar Harhoff. "Recent research on the economics of patents." Annu. Rev. Econ. 4.1 (2012): 541-565.

Hall, Bronwyn H., and Rosemarie Ham Ziedonis. "The patent paradox revisited: an empirical study of patenting in the US semiconductor industry, 1979-1995." RAND Journal of Economics (2001): 101-128.

Hegde, Deepak, and Hong Luo. "Patent publication and the market for ideas." Management Science (2017).

Jaffe, Adam B. "The US patent system in transition: policy innovation and the innovation process." Research policy 29.4 (2000): 531-557.

Kitch, Edmund W. "The nature and function of the patent system." The Journal of Law and Economics 20.2 (1977): 265-290.

Klevorick, Alvin K., et al. "On the sources and significance of interindustry differences in technological opportunities." Research policy 24.2 (1995): 185-205.

Kortum, Samuel, and Josh Lerner. "What is behind the recent surge in patenting?." Research policy 28.1 (1999): 1-22.

Lerner, Josh. "The empirical impact of intellectual property rights on innovation: Puzzles and clues." The American Economic Review 99.2 (2009): 343-348

Lerner, Joshua. "The importance of patent scope: an empirical analysis." The RAND Journal of Economics (1994): 319-333.

Levin, Richard C., et al. "Appropriating the returns from industrial research and development." Brookings papers on economic activity 1987.3 (1987): 783-831.

Mansfield, Edwin, Mark Schwartz, and Samuel Wagner. "Imitation costs and patents: an empirical study." The Economic Journal 91.364 (1981): 907918.

Mansfield, Edwin. "Patents and innovation: an empirical study." Management science 32.2 (1986): 173-181. 
Mazzoleni, Roberto, and Richard R. Nelson. "The benefits and costs of strong patent protection: a contribution to the current debate." Research policy 27.3 (1998): 273-284.

Moser, Petra, and Paul W. Rhode. Did plant patents create the American rose?. No. w16983. National Bureau of Economic Research, 2011.

Moser, Petra. "Determinants of innovation evidence from 19th century World Fairs." The Journal of Economic History 64.2 (2004): 548-552.

Moser, Petra. "How do patent laws influence innovation? Evidence from nineteenth-century world's fairs." The American Economic Review 95.4 (2005): 1214-1236.

Moser, Petra. "Innovation without patents: Evidence from World's Fairs." The Journal of Law and Economics 55.1 (2012): 43-74.

Moser, Petra. "Patents and innovation: evidence from economic history." The Journal of Economic Perspectives 27.1 (2013): 23-44.

Murray, Fiona, and Scott Stern. "Do formal intellectual property rights hinder the free flow of scientific knowledge?: An empirical test of the anticommons hypothesis." Journal of Economic Behavior \& Organization 63.4 (2007): 648-687.

National Research Council. A patent system for the 21st century. National Academies Press, 2004.

Ordover, Janusz A. "A patent system for both diffusion and exclusion." The journal of economic perspectives 5.1 (1991): 43-60.

Ouellette, Lisa Larrimore. "Do Patents Disclose Useful Information?." (2011)

Penrose, Edith Tilton. The economics of the international patent system. No. 30. Baltimore, Md.: Johns Hopkins Press, (1951)

Sakakibara, Mariko, and Lee Branstetter. "Do stronger patents induce more innovation? Evidence from the 1988 Japanese patent law reforms." The Rand Journal of Economics 32.1 (2001): 77.

Schmookler, J. Review of The Economics of the International Patent System. By Edith Tilton Penrose. The Journal of Economic History, 12 (1952): 289-290.

Subramanian, Arvind. "Medicines, patents, and TRIPS." Finance and Development 41 (2004): 22-25.

Taylor, Christopher Thomas, Aubrey Silberston, and Z. A. Silberston. The economic impact of the patent system: a study of the British experience. Vol. 23. CUP Archive, 1973. 
Walsh, John P., Wesley M. Cohen, and Charlene Cho. "Where excludability matters: Material versus intellectual property in academic biomedical research." Research Policy 36.8 (2007): 1184-1203.

Williams, Heidi L. "How Do Patents Affect Research Investments?." Annual Review of Economics 9 (2017): 441-469.

Williams, Heidi L. "Intellectual property rights and innovation: Evidence from health care markets." Innovation Policy and the Economy 16.1 (2016): 53-87.

\section{Figures}




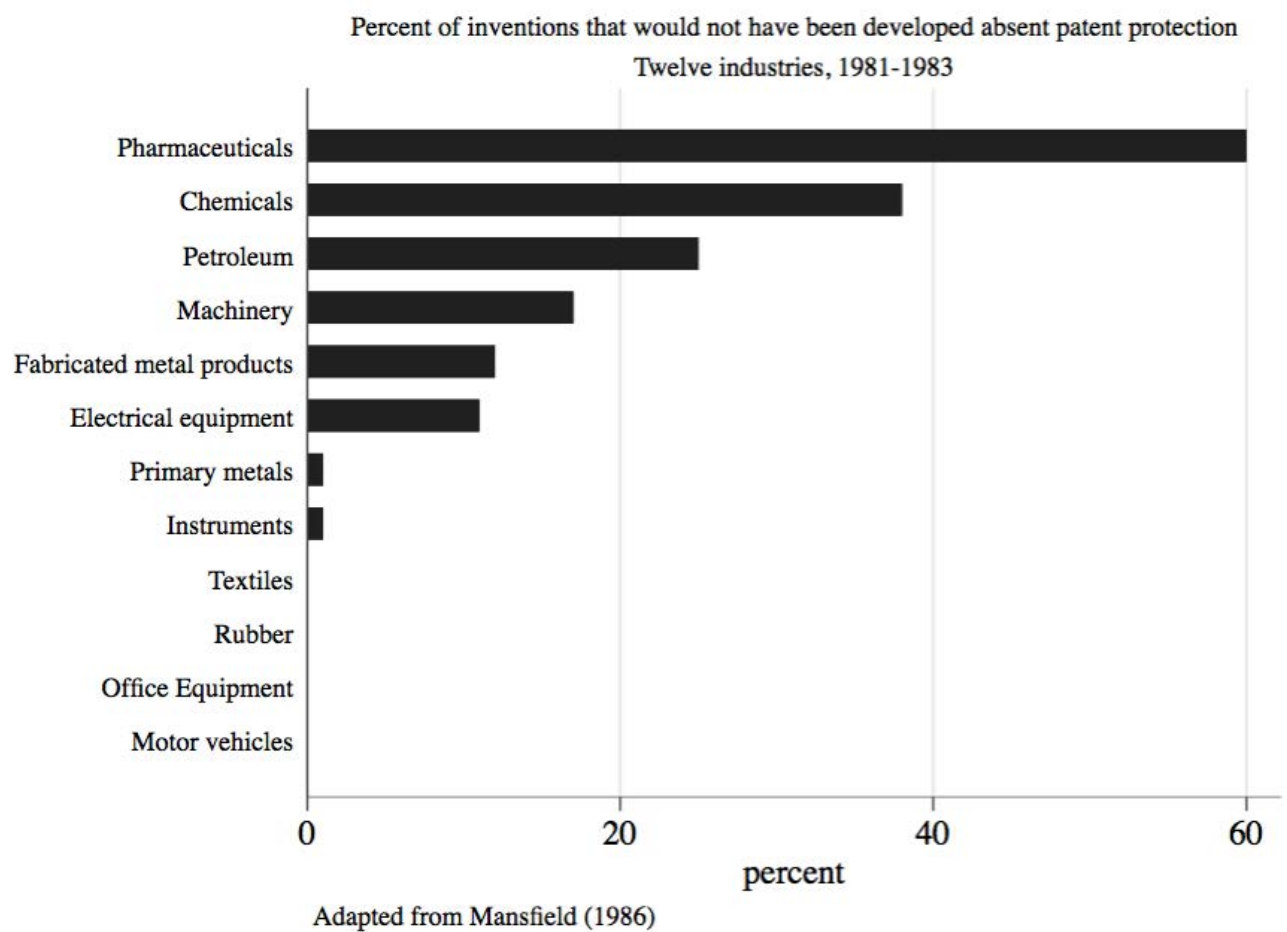

Figure 1: Mansfield surveyed a random sample of 100 large R\&D intensive firms asking them the percent of inventions that would not have been developed absent patent protection. Mansfield found sharp cross-industry differences in the importance of patents, with respondents indicating that 60 percent of drug inventions and 38 percent of chemical inventions would not have been developed in pharmaceuticals and chemicals respectively. In most other industries, responses suggested the vast majority of inventions would have been developed without patent protection. 


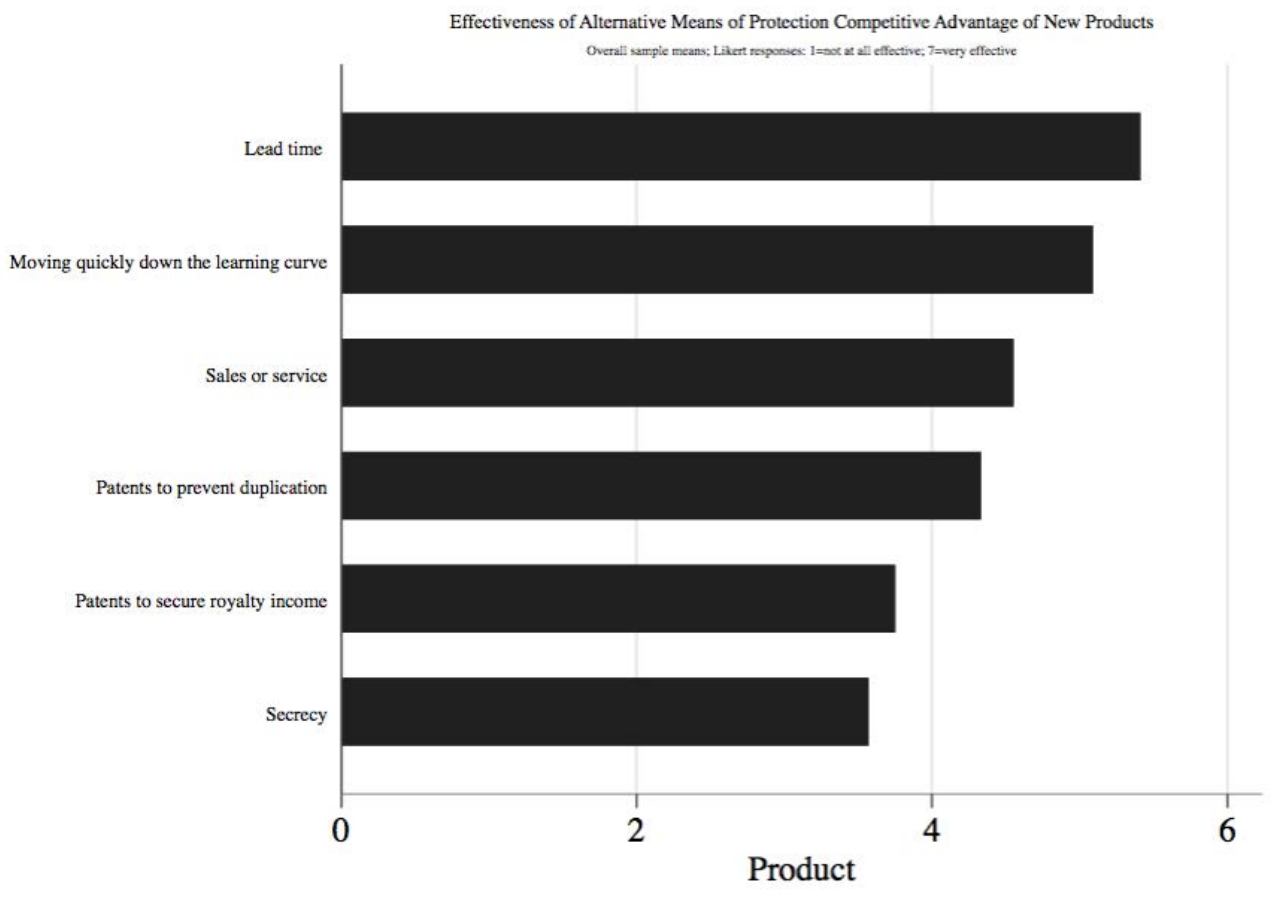

Adapted from Levin et al (1987) Table 1

Figure 2: The Yale survey asked R\&D managers from public firms about the effectiveness of patent protection relative to other means of protecting competitive advantage of new products. Overall across industries learning curves, complementary assets (sales, service) ranked higher than patents as a way to appropriate returns from innovation. 


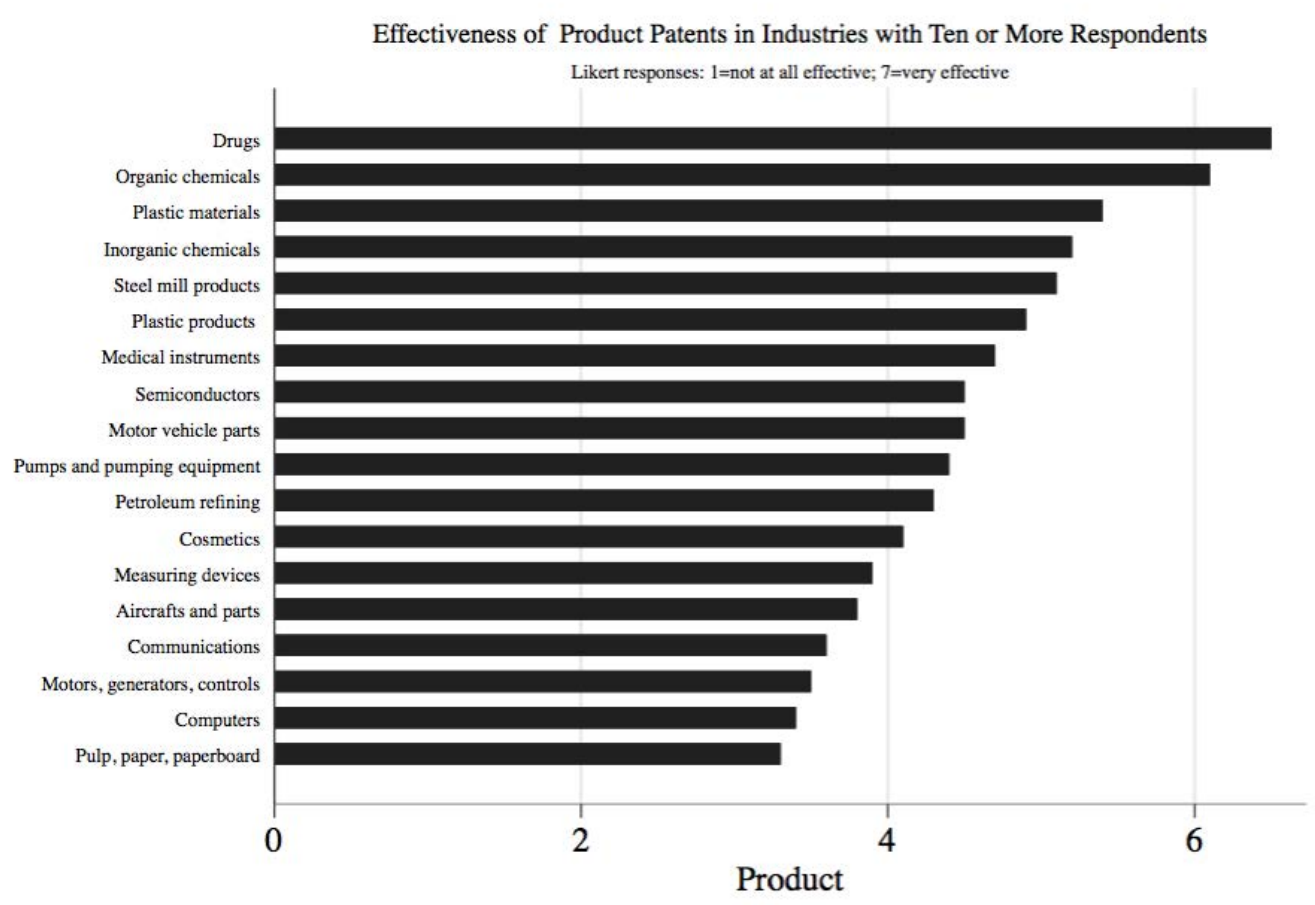

Adapted from Levin et al (1987) Table 2

Figure 3: The Yale survey also found interindustry differences, with patents more effective in pharmaceuticals and chemicals than other fields. 


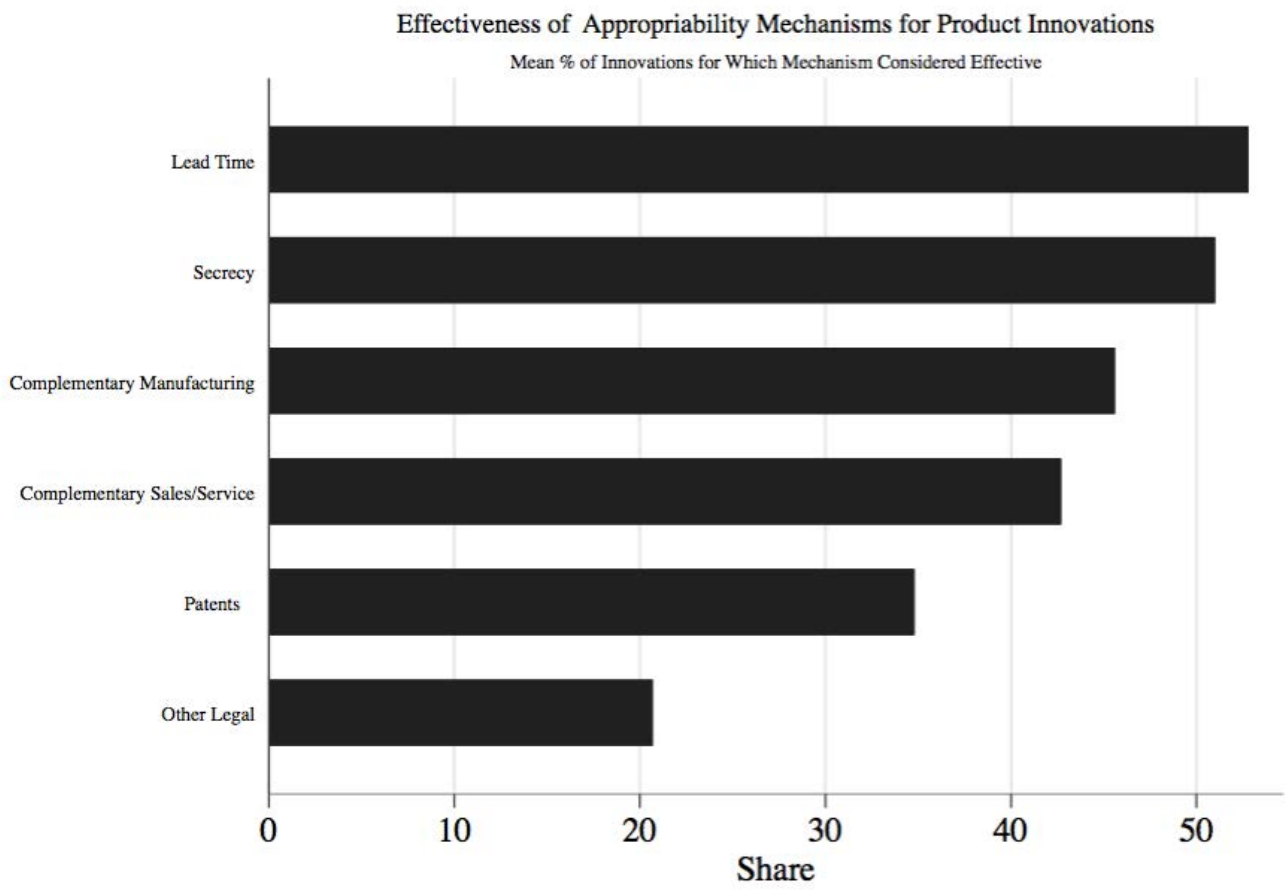

Adapted from Cohen et al (2000) Figure 1

Figure 4: The Carnegie Mellon survey was administered to R\&D labs in the U.S. manufacturing sector in 1994. It sampled 3240 labs and received 1478 responses. Overall, patents were reported to be the least important of the major apppropriability mechanisms. 


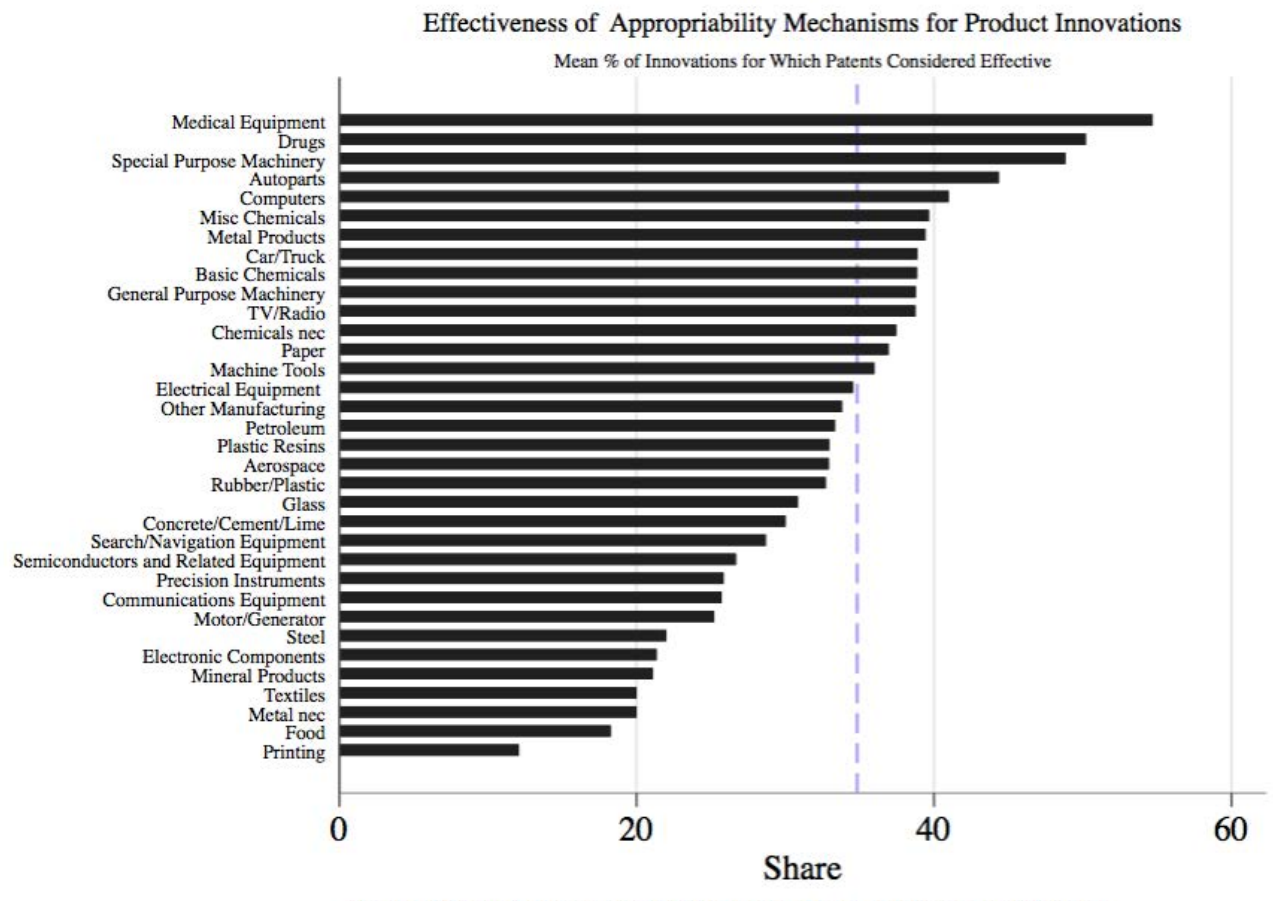

Adapted from Cohen et al (2000) Table 1. Vertical line at overall mean

Figure 5: Notes: The Carnegie Mellon survey was administered to R\&D labs in the U.S. manufacturing sector in 1994. It sampled 3240 labs and received 1478 responses. This figure shows the mean percentage of product innovations for which patents were considered effective, by industry. The vertical line is at the cross-industry average. 


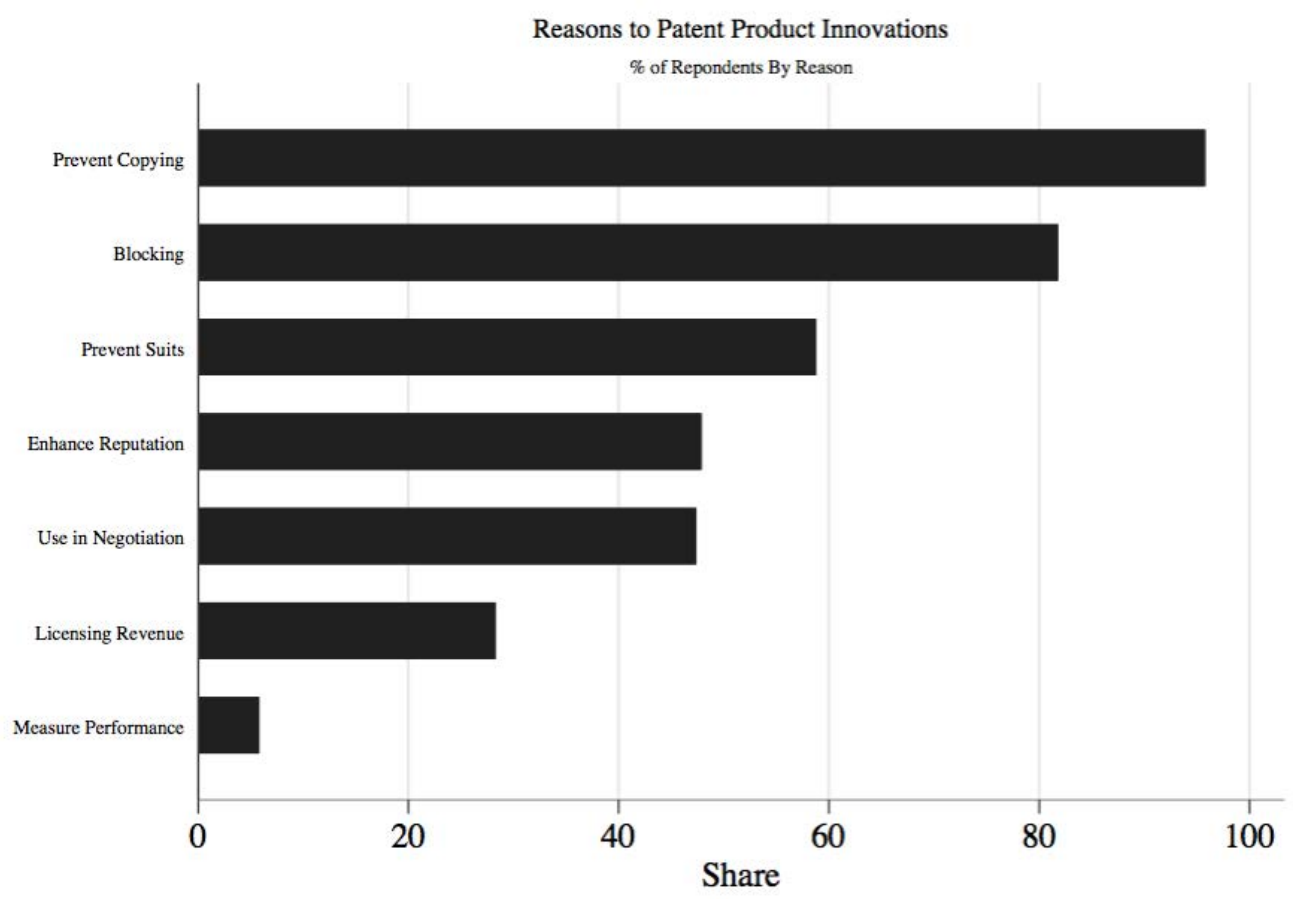

Adapted from Cohen et al (2000) Figure 7.

Figure 6: The Carnegie Mellon survey was administered to R\&D labs in the U.S. manufacturing sector in 1994. It sampled 3240 labs and received 1478 responses. This chart shows responses to a question about reasons the firms applied for patents on their most recent product innovation. While the for 92 percent of the inventions the classic rationale, preventing copying, was mentioned, blocking rival patents on related innovations was listed for 82 percent and preventing lawsuits for 58 percent. 
Importance of mechanism for capturing competitive advantage from technology

Likert responses: $1=$ not important at all; $2=$ =slightly; $3=$ moderately; $4=$ very

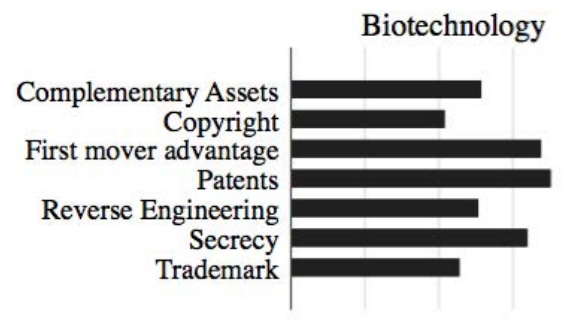

Software

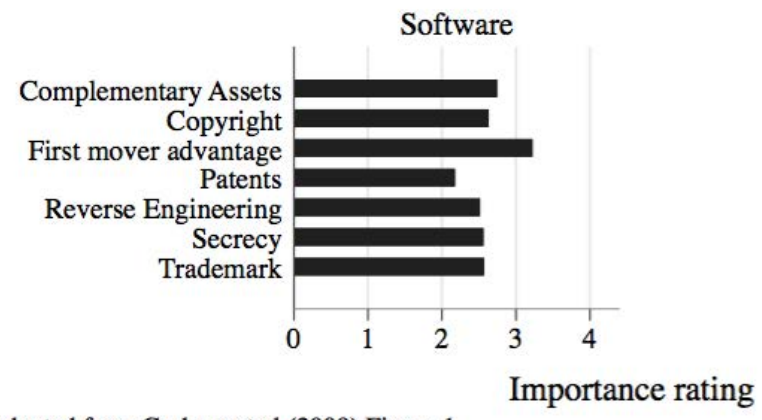

Adapted from Graham et al (2009) Figure 1.

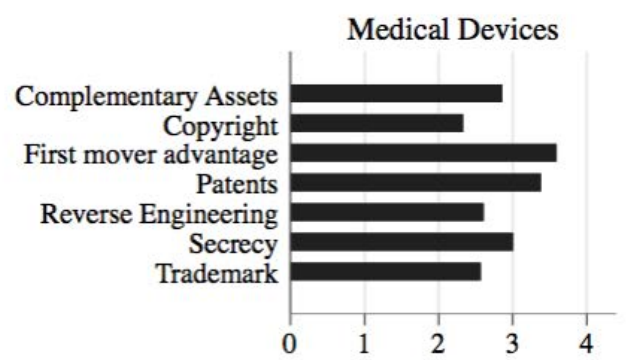

Adapted from Graham et al (2009) Figure 1.

Figure 7: The Berkeley survey focused on 1,332 early stage companies founded since 1998. This figure shows average industry ratings of the importance of different appropriability strategies. Specifically, respondents were asked "How important or unimportant is each of the following in your company's ability to capture competitive advantage from its technology inventions?" Among biotechnology companies patents were ranked as the most important, and among medical device firms the second most important (after first mover advantages). 


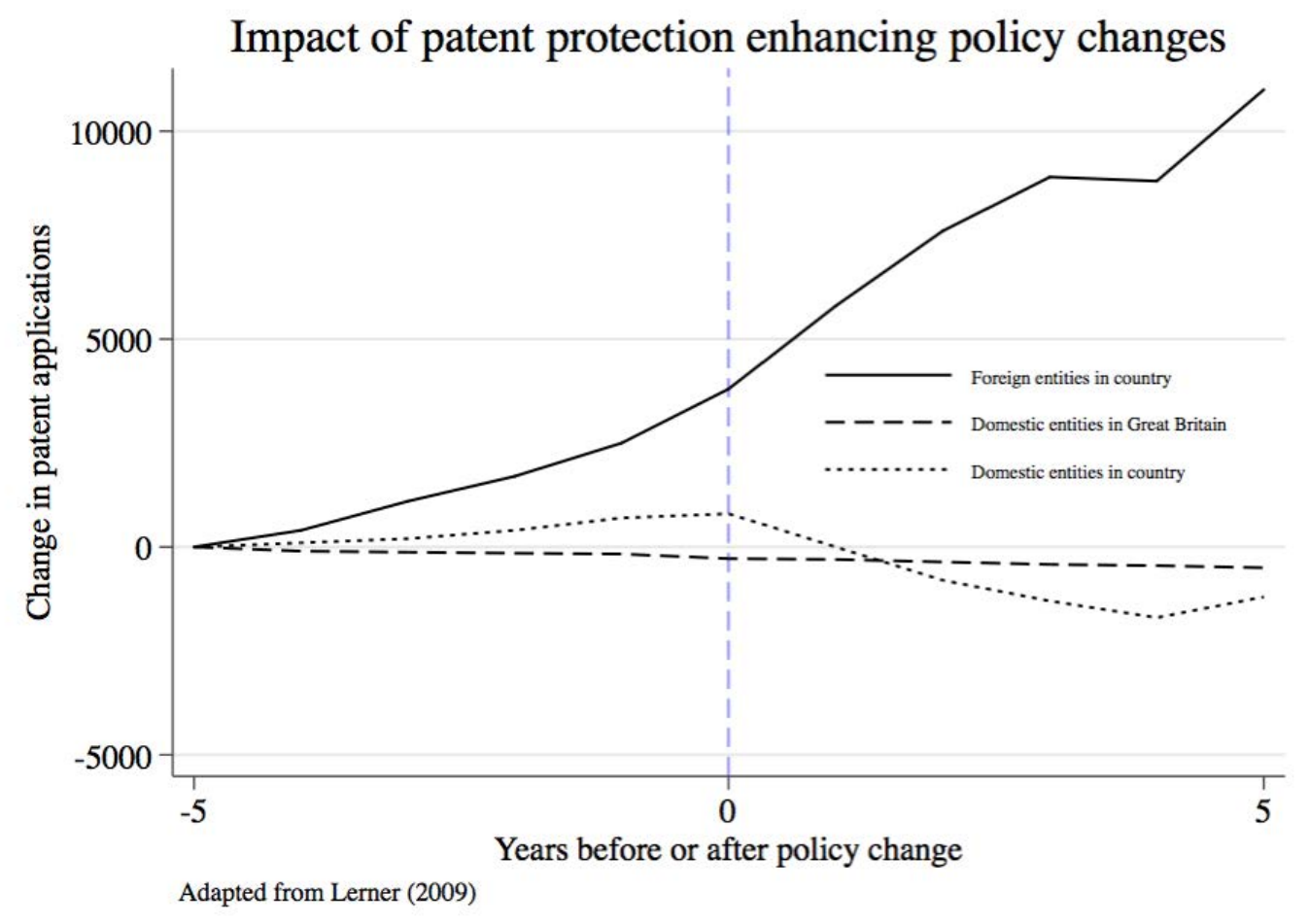

Figure 8: Lerner examined how strength of patent protection in 60 countries between 1850 and 1999 related to innovation, as measured by patent filing in Great Britain. He also examines the effects of strengthening on patent applications by domestic and foreign entities in the country affected. The dashed blue line shoes timing of the patent policy change. Note that the amount of domestic innovation, as measured by patenting in Great Britain, was unaffected by these changes. 


\section{Time trend of log citation-weighted pharmaceutical patents}

Countries that implemented pharmaceutical patent laws 1978-1999

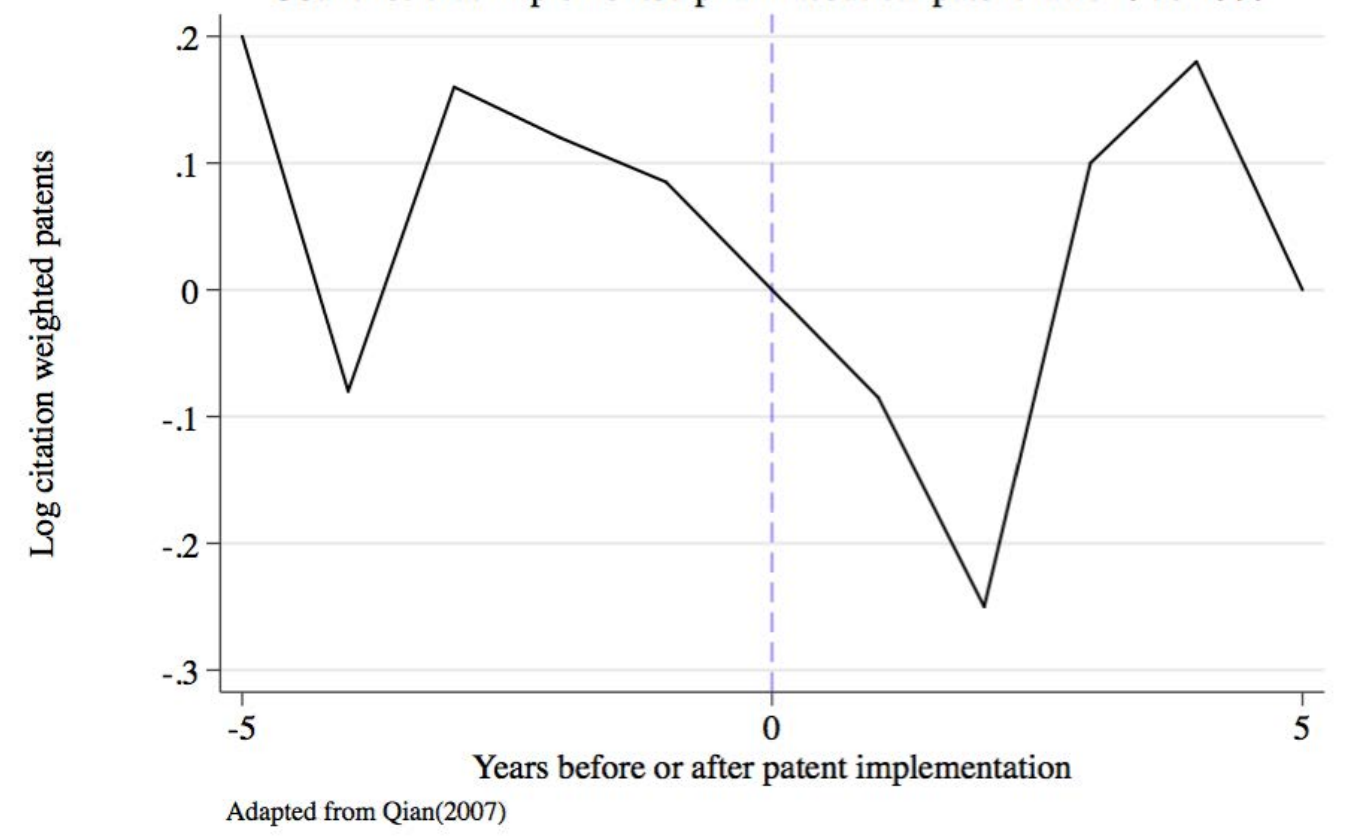

Figure 9: Qian (2007) examined innovation in 26 countries that established pharmaceutical patent laws during the 1978-2002 period. This chart shows trends in citation weighted pharmaceutical patent counts in the U.S. by firms in a country, before and after that country implemented pharmaceutical patent protection. 
Estimated relationship between drugs in trials and deaths from a disease By type of disease, income of country, patent status of country

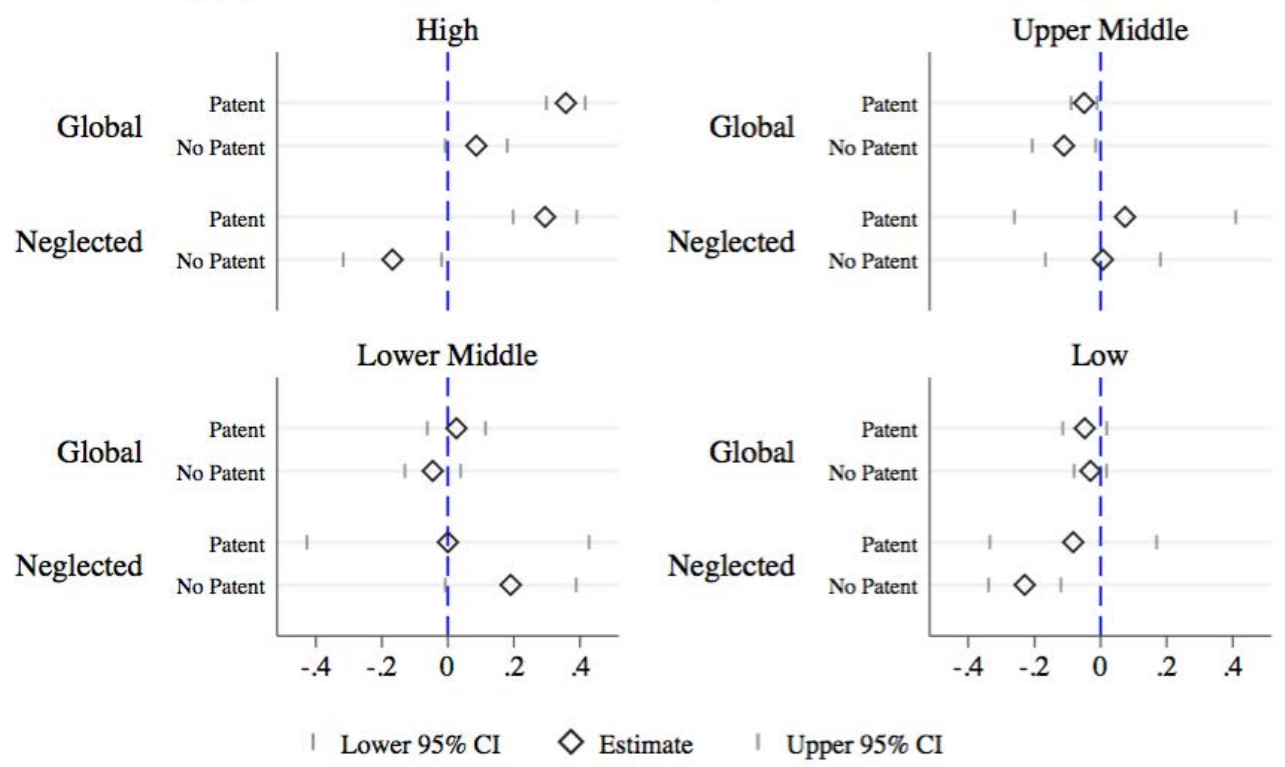

Adapted from Kyle and McGahan (2012) Table 2; Coefficients from negative binomial regressions

Figure 10: Kyle and McGahan (2012) used data on research on different diseases (as measured by the number of drugs in Phase I trials) and relate to market size of that disease. This chart shows responsiveness of research to market size for different types of diseases in different types of countries, including those with and without drug patent protection, over the 1990-2006 period. Neglected diseases are defined as those which disproportionately affect developing countries, for which new treatments are needed, and for which no commercial market is thought to exist. The diamonds represent coefficients from negative binomial regressions where the dependent variable is the number of new phase one trials for a disease in a given year, and the independent variables are the log of market size for a disease in countries with and without patent protection, interacted with indicators for type of disease and type of country. The dashes indicate 95 percent confidence intervals. In high income countries, for both global and neglected diseases, $\mathrm{R} \& \mathrm{D}$ is more responsive to market size when there is patent protection. However, across lower income countries there is no significant difference in the responsiveness of $R \& D$ to market size (for any type of disease) between patent protected and non-patent protected countries. 


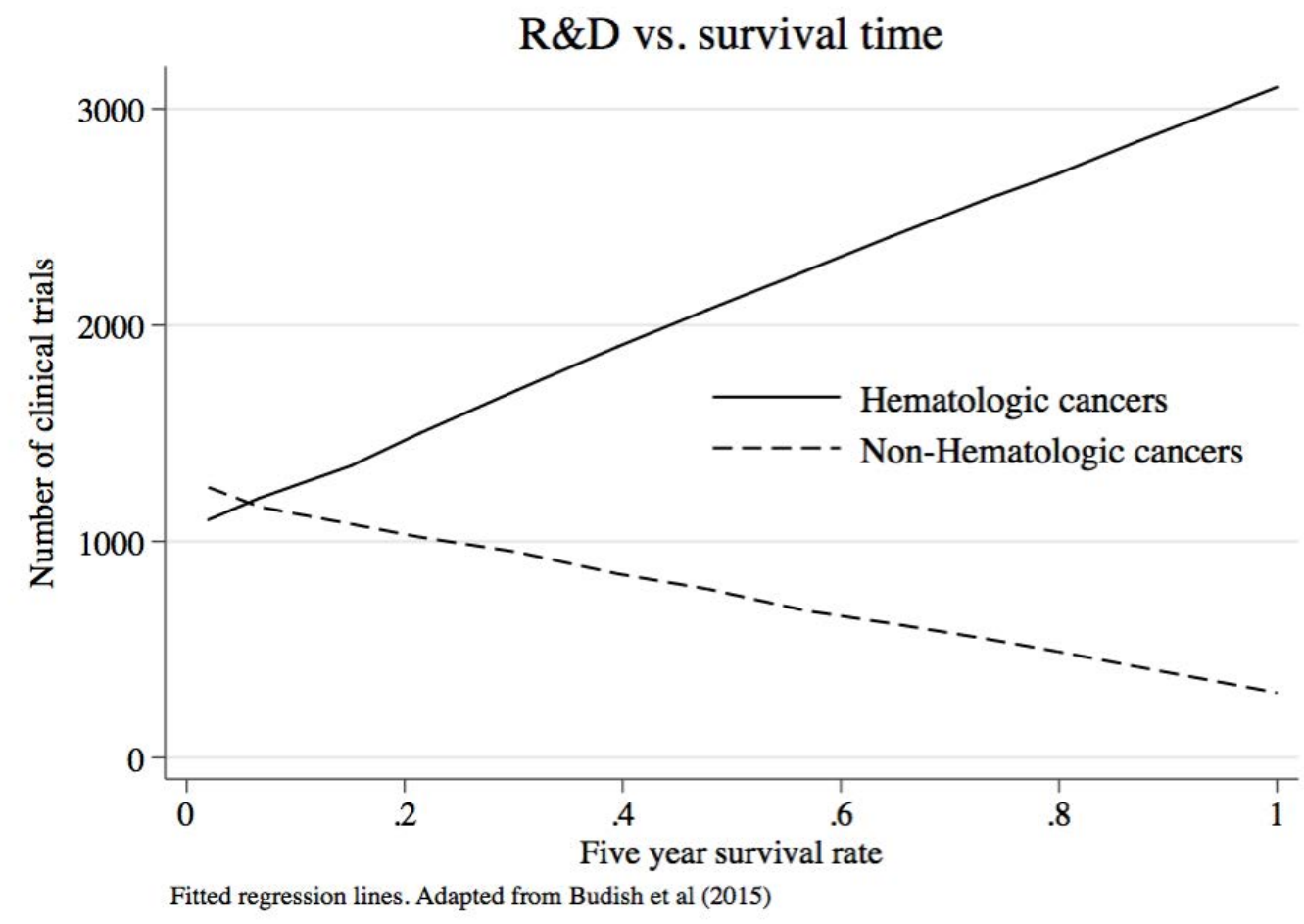

Figure 11: Budish et al. (2015) relate the number of clinical trials for cancer drugs to five year survival rates for those cancers. This figure plots regression line summarizing the bivariate relationship, estimated at the cancer-stage level between 1973 and 2004. In their main analyses for non-hematologic cancers, they find a negative relationship, plotted by the dashed line. Longer survival times may mean less effective patent protection, so this is consistent with the idea that shorter patent terms lead to less research. To rule out the possibility that this is due to other factors associated with longer survival times (e.g. scientific opportunity) they also looked at hematologic cancers. Since hematologic cancers are approved based on surrogate endpoints, there is no link between survival time and patent term. For these cancers, the authors do not find a negative relationship between survival time and research. Similar results are seen in regression models which control for market size and other variables. 
For Unpatented Innovations Most Important Reasons Not to Patent $\%$ of Repondents By Reason

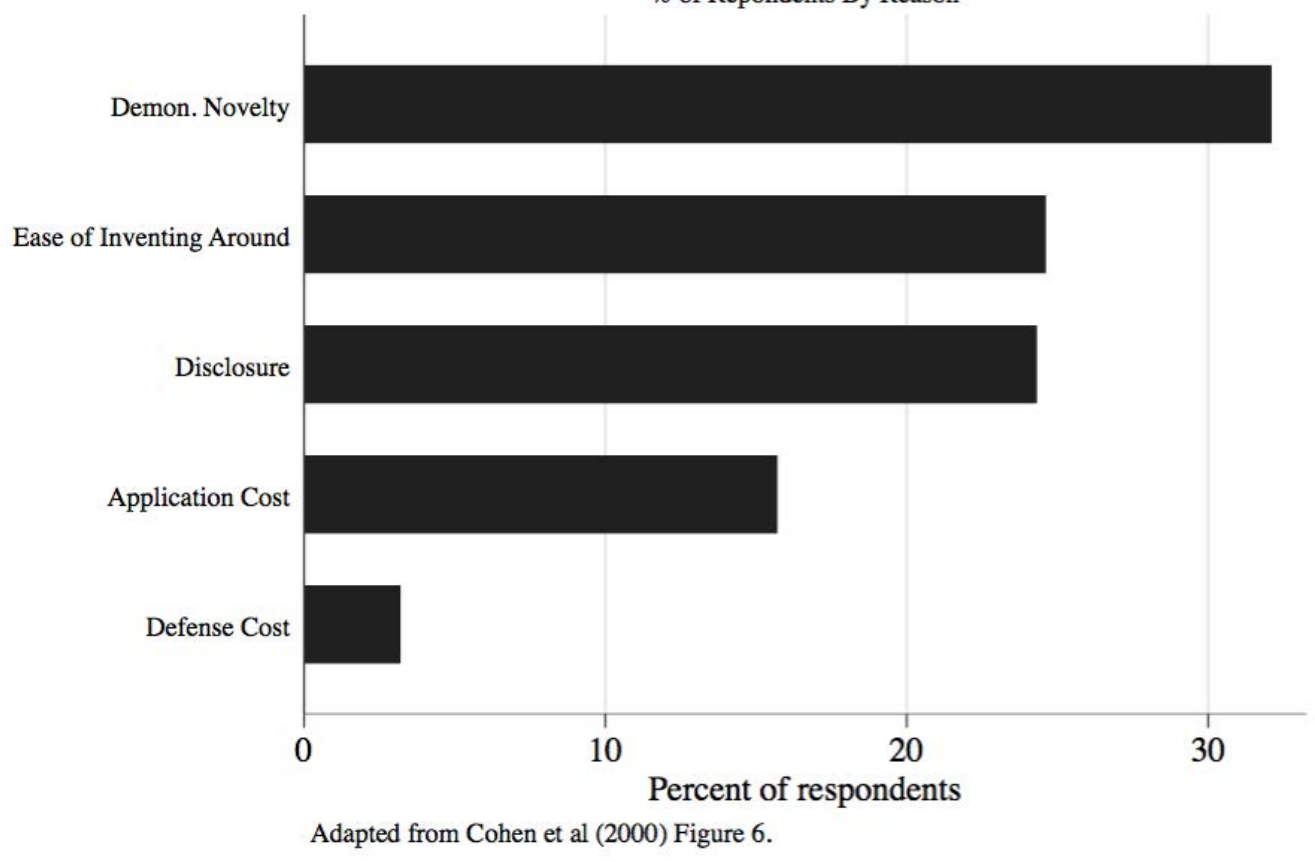

Figure 12: The Carnegie Mellon survey was administered to R\&D labs in the U.S. manufacturing sector in 1994. It sampled 3240 labs and received 1478 responses. This figure shows responses to a question about reasons that contributed to decisions to not apply for a patent (for the most recent invention they decided not to patent). Inventing around and disclosure (together) were cited nearly half of the time, providing indirect evidence that patents disclose useful information. 


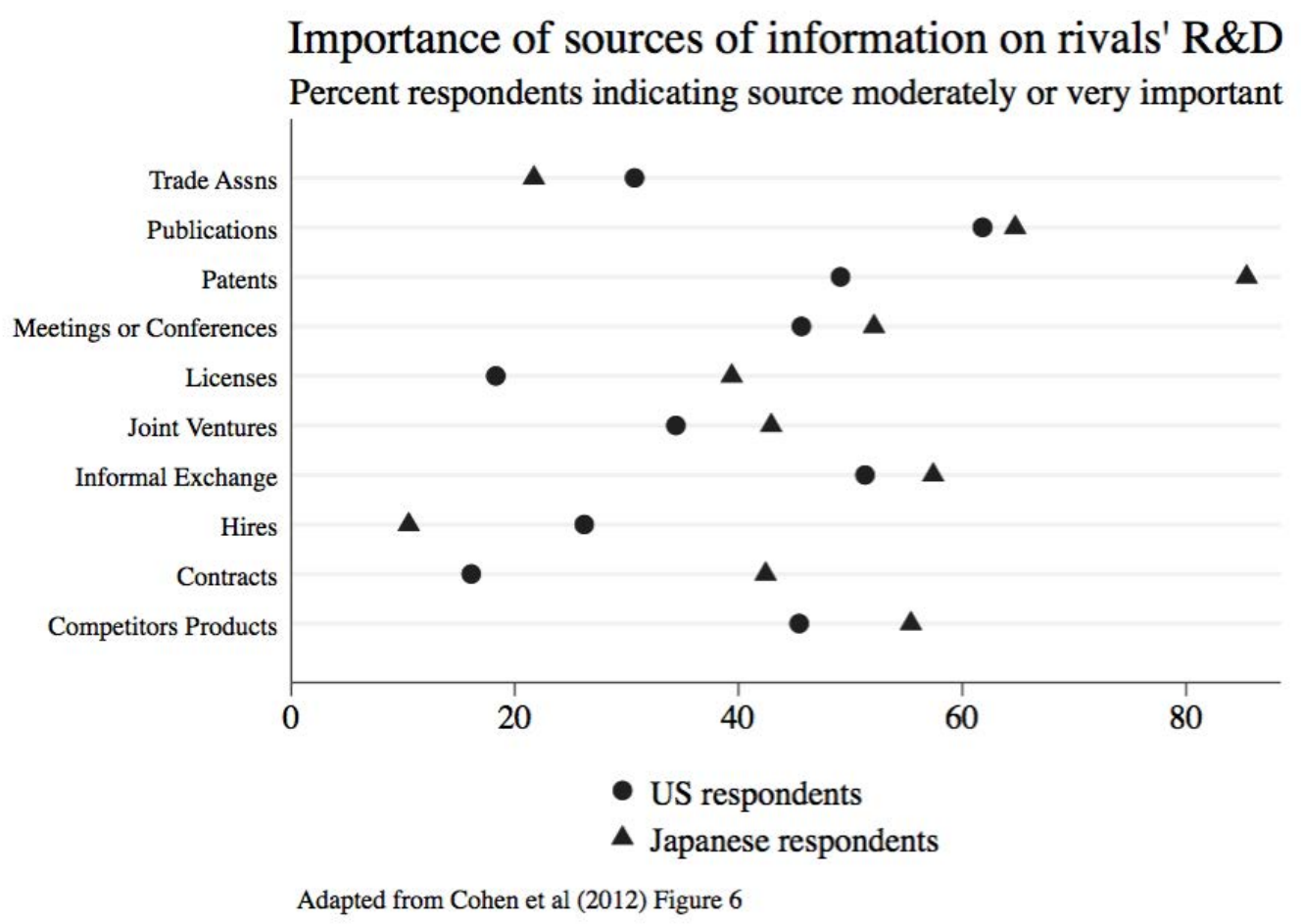

Figure 13: The Cohen et al. (2002) survey of R\&D managers of U.S. and Japanese manufacturing firms. Among other questions, the survey asked firms about patents versus other sources of information. Specifically, it asked both U.S. and Japanese respondents to score on a four-point Likert scale the importance to a recent major $R \& D$ project of different information sources. Japanese respondents were much more likely to report that patents were moderately or very important, and patents were reported to be the main information source in Japan. In the U.S., patents are ranked third, behind publications and informal information exchange. 


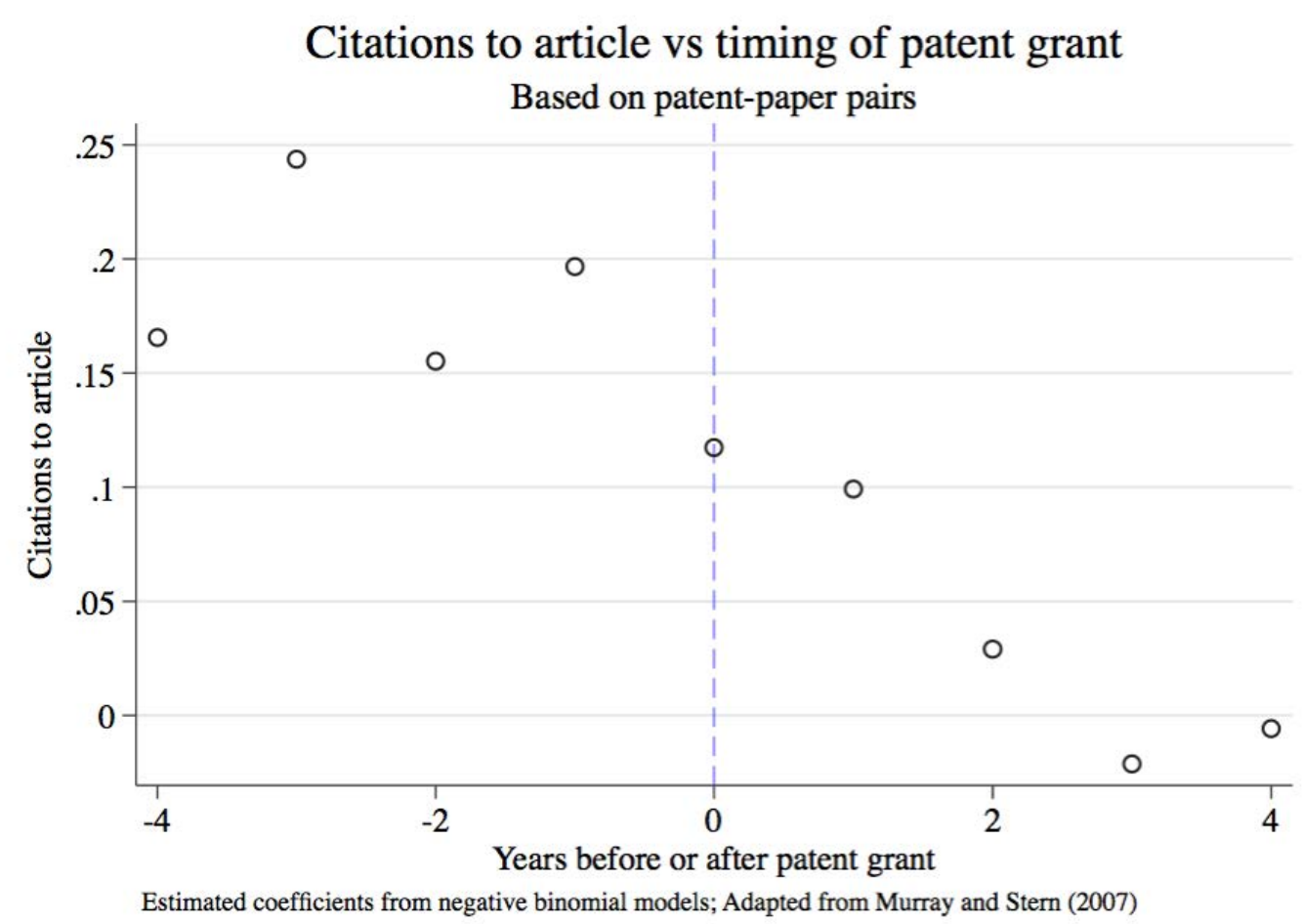

Figure 14: Murray and Stern examine patent-paper "pair" based on 340 articles published in Nature Biotechnology between 1997 and 1999. Patentpaper pairs are cases where the information in the article was covered by a patent. About half (169) were granted patents by 2003. This figure shows estimates from negative binomial regressions with the number of citations to the article as the dependent variable and years before and after patent grant as independent variables. The model includes article fixed effects, controlling for the average quality of the article. The results suggest that citations to the articles decline after patent grant: about a 25 percent difference between the pre-grant average and the citation level four years after patent issue. However, a later study by the same authors (Fehder, Murray, and Stern 2014) which includes a longer span of articles (1997-2005) found that this initial negative impact was reversed in later years, and patents overall have a positive effect on follow-on innovation. Rather than hindering follow-on research, the authors suggest that once a journal becomes established it may actually help facilitate "markets for technology" for patented research. 


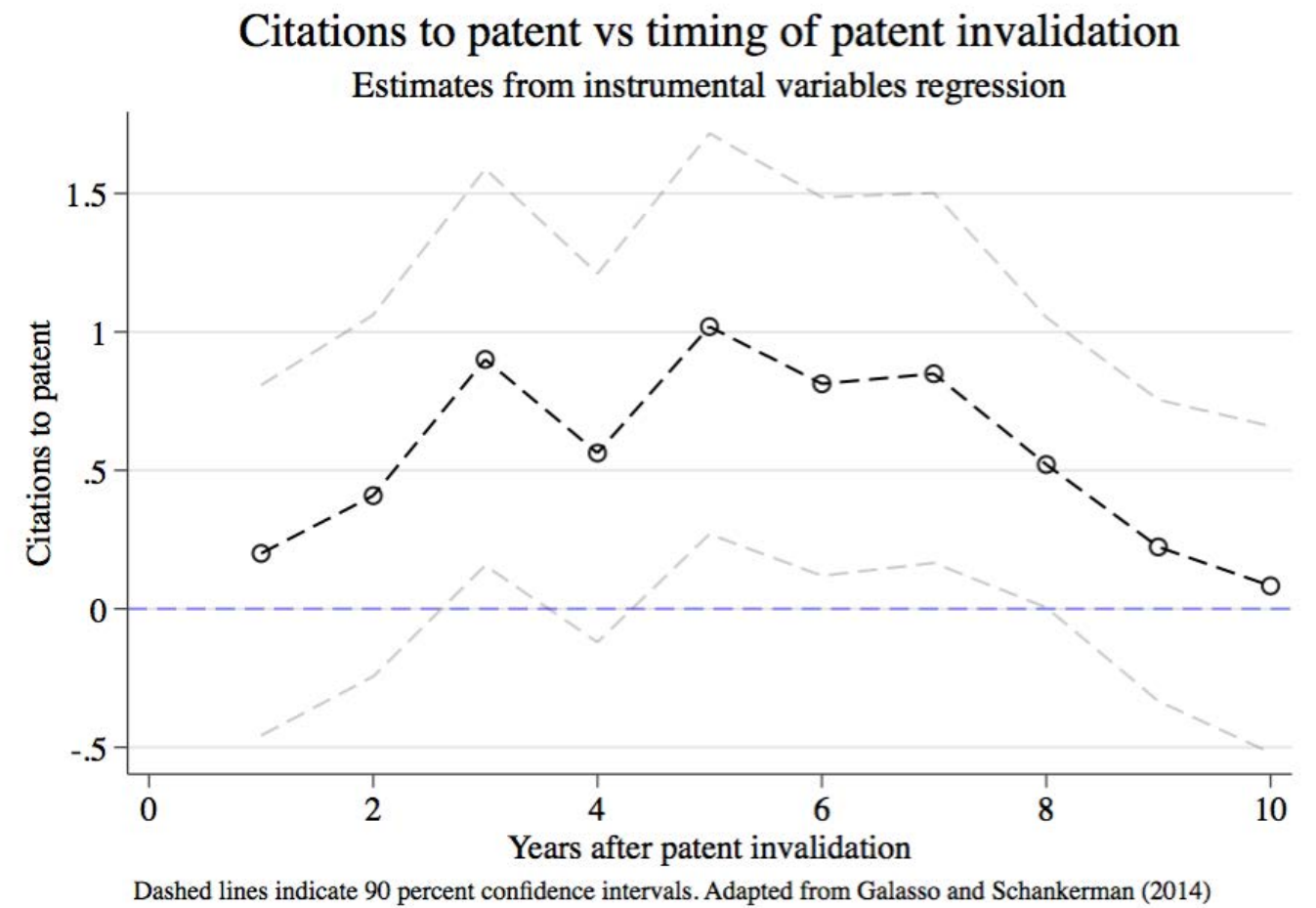

Figure 15: The authors examine 1,258 patents that were subject to Federal Circuit validity decisions, and measure how follow-on research (proxied by citations to the focal patent) changes if patents are invalidated. The study takes advantage of the fact that judges assigned to patent cases are randomly assigned and have different levels of invalidation, creating a natural experiment to assess the causal impact of patent invalidation. Citations to the invalidated patents are significantly higher than those to patents that were not invalidated, controlling for earlier citation trends, year, age, and field effects, suggesting that patents block subsequent innovation. This figure shows instrumental variables estimates of the time path of the effect: it is statistically significant between years 2 and 7 after patent invalidation. 